\title{
Achieving the Paradox of Concurrent Internationalization Speed: Internationalizing Rapidly in Both Breadth and Depth
}

\section{Georgios Batsakis $^{1,2}$ (D) Vasilis Theoharakis ${ }^{3}$}

Received: 28 August 2020 / Revised: 13 July 2021 / Accepted: 5 August 2021 /

Published online: 10 September 2021

(c) The Author(s) 2021

\begin{abstract}
In this paper, we draw on the notions of breadth and depth of internationalization speed in an attempt to examine the performance implications for multinational enterprises (MNEs) that rapidly and concurrently internationalize in new and existing foreign markets. Specifically, we examine the organizational paradox which suggests that firms which grow internationally by concurrently expanding rapidly in both new foreign markets (breadth) and in foreign markets they currently operate (depth), are better off than firms which do not adopt such an approach. Since past research has not examined the interaction between the breadth and depth of MNE internationalization speed on firm performance, we contribute to the temporal dimension of the internationalization process by developing a novel, yet paradoxical approach. Our analysis is based on a longitudinal sample of the world's largest retail MNEs covering the period 2003-2012, which includes the 2008 financial crisis that had a significant effect on the global economy. We find that concurrent internationalization speed positively relates to firm performance during periods of stability. Further, we draw from the upper-echelons theory and find that the aforementioned relationship can be strengthened by the level of CEO international experience and CEO education.
\end{abstract}

Keywords Concurrent internationalization speed $\cdot$ Breadth of internationalization speed $\cdot$ Depth of internationalization speed · Paradox theory $\cdot$ Upper echelons theory $\cdot$ Firm performance

Georgios Batsakis

georgios.batsakis@brunel.ac.uk

1 Brunel Business School, Brunel University London, Kingston Lane, UB8 3PH Uxbridge, UK

2 Alba Graduate Business School, The American College of Greece, Athens, Greece

3 Cranfield School of Management, Cranfield University, Cranfield, UK 


\section{Introduction}

The internationalization process is considered one of the most important tenets of corporate strategy (Melin, 1992; Vermeulen \& Barkema, 2002). Therefore, MNEs have been interested in gaining a better understanding on why (e.g., market-, resource-, efficiency-, innovation-seeking motives), where (e.g., location choice, geographic scope) and how (e.g., foreign market entry mode choice, the role of distance) to internationalize (Eden, 2009) in order to maximize the benefits (Hennart, 1982; Hymer, 1960; Vernon, 1966), and minimize the costs stemming from foreign expansion (Dierickx \& Cool, 1989). More recently, a fourth area of concern, relating to when to internationalize, has emerged. This temporal dimension of the internationalization process (such as the timing of entry and speed of internationalization), has been receiving considerable attention in international business (IB) research (e.g., Casillas \& Moreno-Menéndez, 2014; Hitt et al., 2016; Jiang et al., 2014; Qian et al., 2018).

The emphasis on time-related aspects of the internationalization process in general, and internationalization speed in particular, has been stressed by several scholars. For example, in their seminal paper, Jones and Coviello (2005, p. 284) present internationalization as "a time-based process", suggesting that it is essential for a temporal dimension, such as speed, to be explicitly incorporated in the analysis of the internationalization process. In the same vein, Chetty et al. (2014) view internationalization speed as a process and raise the importance of the managerial challenge firms encounter in their decision-making. This is also reflected by the increasing research attention on the performance implications of internationalization speed (García-García et al., 2017; Mohr \& Batsakis, 2017; Powell, 2013; Yang et al., 2017).

Despite the mounting interest towards explaining the determinants of internationalization speed (Li et al., 2015) and its performance effects (Kim et al., 2020), this research territory still remains largely uncharted (Hitt et al., 2016). More specifically, since internationalization is such a time-dependent process, one might not afford to grow in incremental steps, or even at a high pace in a single direction, which has been the focus of extant research. However, a paradox does arise when firms attempt to grow rapidly by concurrently internationalizing their activities in terms of both breadth and depth. From an IB perspective, breadth refers to the dispersion of growth as demonstrated by entries in new foreign markets over a given period of time, while depth refers to the extent by which, resources are committed to scale operations in a given period of time in markets where the firm already operates. In an attempt to explain the difference between the two, De Bono (1971) puts forward an analogy; "breadth refers to digging a new hole elsewhere, whereas depth refers to digging the same hole deeper" (Nadkarni et al., 2011 , p. 512). Given that the simultaneous commitment to rapid internationalization in terms of both breadth and depth (i.e., concurrent rapid internationalization) can lead to organizational tensions, we consider such a strategy to be paradoxical since these two dimensions are contradictory, interrelated, simultaneous and persistent over time (Pant \& Ramachandran, 2017). In essence, this does not 
only imply that one is digging new holes elsewhere while making the existing hole deeper, but they are also doing so very fast.

Although the relationship between internationalization speed and firm performance has received a lot of attention recently (García-García et al., 2017; Mohr \& Batsakis, 2017; Powell, 2013; Yang et al., 2017), a significant missing link exists: The interaction between different process-oriented dimensions of internationalization speed. While the literature has examined different dimensions of internationalization speed in isolation (Chetty et al., 2014; Hilmersson \& Johanson, 2016), or jointly but with respect to other outcomes such as firm survival (Meschi et al., 2017), ${ }^{1}$ it still remains unclear how the interaction of two process-oriented dimensions of internationalization speed such as breadth and depth relate to firm performance. The interaction between the two dimensions offers important theoretical implications. First, the revisited Uppsala internationalization process model (Johanson \& Vahlne, 2009) considers that firm international growth comprises of two stages; recognition (i.e., exploration) and exploitation of an opportunity. In their revisited model, Johanson and Vahlne (2009) argue that international growth is a process characterized by gradually and sequentially increasing recognition (exploration) and commitment (exploitation) of an opportunity, thus suggesting that firms need to expand in one dimension (either exploration or exploitation) at a time (i.e., following a sequential process). Similarly, the Penrosean lenses support that resource-related constraints associated with fast firm growth will eventually lead to decreasing performance (Penrose, 1959). We argue that breadth and depth of internationalization speed, when considered jointly and not in isolation, can be positively related to performance. We draw on paradox theory which supports that successfully managing seemingly conflicting strategies (i.e., breadth and depth of internationalization speed) would eventually lead to increased performance (Lewis, 2000). Second, the paradoxical and demanding strategy of concurrent internationalization speed, may make the organization appear to operate on the edge of chaos (Eisenhardt \& Brown, 1998) which would require the appropriate senior executives to help it navigate. Therefore, we draw from the upper echelons (UE) theory (Hambrick \& Mason, 1984) and hypothesize that capable leaders carry value-added knowledge, experience and information which is needed to deliver on such paradoxical requirements (Wang et al., 2018). We thus proceed by investigating how CEO characteristics moderate the relationship between concurrent internationalization speed and firm performance. UE-based research has long suggested that the personal attributes and characteristics of managers should be such that can enable them to process information efficiently in order to deal with complex decision-making and ambiguity in their international tasks (Herrmann \& Datta, 2002). Also, considering the proven link between entrepreneurial firms and the adoption of rapid internationalization (Jones \& Coviello, 2005; Oviatt \& McDougall, 2005; Xue et al., 2021), we argue that CEOs in their risk-taking approach with regards to internationalization

\footnotetext{
1 The paper by Meschi et al. (2017) examines the joint effect of firm age at internationalization and market expansion speed. We consider the former dimension (age at internationalization) to be non-processoriented.
} 
processes such as rapid internationalization, can be linked with two observable moderators, these of CEO international experience and CEO education, as proxies of their knowledge capacity, cognitive orientation and ability to effectively process complex information.

This study contributes to the international strategy literature in general, and the temporal dimension of internationalization in particular in three ways. First, it explores the important and under-researched issue of the interaction between the breadth and depth of internationalization speed and why these two dimensions can concurrently have positive performance implications. Our findings confirm that when the two dimensions are jointly considered they are characterized by having a positive effect on firm performance. Second, this study extents the theoretical logic on the relationship between internationalization speed and firm performance. So far, the Uppsala model and the Penrosean lenses, among others, have dominated the discussion as the most effective theoretical underpinnings employed to explain the internationalization speed phenomenon. We integrate an interdisciplinary, yet widely used theory (paradox theory), which has received little attention in the IB literature (Pant \& Ramachandran, 2017). We thus aim at explaining the internationalization speed phenomenon from a different, yet informative and relevant theoretical perspective. Third, this study is the first to demonstrate how CEO characteristics associated with knowledge capacity, cognitive orientation and ability to effectively process complex information influence the relationship between concurrent internationalization speed and firm performance. Thus, we add an extra layer of knowledge on the contingent nature of the relationship between internationalization speed and firm performance by integrating insights from the UE perspective.

We test our hypotheses against a panel dataset comprising the largest retail MNEs over the 10-year period 2003-2012 and find support for our conjectures. These retail MNEs are predominantly headquartered in developed markets that were hit hard by the 2008 financial crisis potentially resulting in financial constraints. For that reason, the selection of this particular period allows us to examine our hypotheses during a period of economic stability and a period of economic crisis where international expansion investments might have been adversely affected (Lee \& Makhija, 2009).

\section{Theoretical Background and Hypotheses Development}

\subsection{Conceptualization of Rapid Internationalization in the IB Literature}

Rapid internationalization can be defined, conceptualized and operationalized in different ways (Chetty et al., 2014; Hitt et al., 2016). Some studies, mainly in the born globals (BG) literature, conceptualize internationalization speed based on the time lag between a firm's inception and its first international expansion (Acedo \& Jones, 2007; Cavusgil \& Knight, 2015; Chetty \& Campbell-Hunt, 2004; Zahra et al., 2000). Other studies which focus on larger, long-established MNEs, conceptualize speed as a firm's subsequent international operations' expansion in scale or scope over a given period of time (Chang \& Rhee, 2011; Vermeulen \& Barkema, 2002) or 
through counting the number of days between two internationalization episodes of the focal firm (Tang, 2019).

Our study draws on established research and supports the view that, with the exception of a few recent studies which have considered different dimensions when assessing internationalization speed (e.g., Casillas \& Moreno-Menéndez, 2014; Hilmersson \& Johanson, 2016; Hsieh et al., 2019; Meschi et al., 2017), the vast majority of existing studies tends to adopt a unidimensional view on rapid internationalization which cannot fully capture the dynamics of its complexity (Chetty et al., 2014). Consequently, this leads to the need for (i) a more systematic study of the effect of multidimensional conceptualizations and operationalizations of rapid internationalization and (ii) the examination of the potential interactions of different forms of rapid internationalization on firm performance. We claim that extant literature has not so far attempted to convincingly assess the dynamics of the interaction of two or more forms of process-oriented dimensions of internationalization speed on firm performance. In this study we consider and assess the interaction of the widely adopted forms of breadth and depth of internationalization speed. Further, we initiate our hypothesis development based on a relationship between breadth of internationalization speed and performance which has not been tested extensively. Next, drawing on the paradox perspective, we aim to substantially contribute in the literature through shedding light into the interaction of breadth and depth of internationalization speed. Finally, using an upper echelons perspective lens we examine the moderating effect of CEO characteristics on the relationship between breadth and depth of internationalization speed and firm performance.

\subsection{Breadth of Internationalization Speed and Firm Performance}

IB literature did place an early focus on an incremental commitment to internationalization with the Uppsala model which has dominated the field (Johanson \& Vahlne, 1977; Vahlne \& Johanson, 2017). The proponents of this incremental internationalization suggest that the process is sequential with a focus on geographic and psychic proximity (Barkema et al., 1996; Hutzschenreuter \& Voll, 2008). While a number of studies which mainly draw their insights on the staged theory of firm internationalization (Johanson \& Vahlne, 1977) and the notion of time compression diseconomies (Dierickx \& Cool, 1989) conclude that firms benefit from a slow and incremental internationalization process (Barkema \& Drogendijk, 2007; Jiang et al., 2014), other studies find that firms gain more benefits when adopting a higher pace of internationalization (Bonaglia et al., 2007; Luo \& Tung, 2007; Mathews, 2006; Powell, 2013). Others have argued that the relationship between rapid internationalization and firm performance is more complicated where initial net benefits stemming from rapid international expansion give way to diminishing returns followed by a significant drop in firm performance (García-García et al., 2017; Mohr \& Batsakis, 2017; Yang et al., 2017). Therefore, extant empirical research investigating the effect of rapid internationalization on firm performance has come up with mixed findings. 
The focus of our base hypothesis is the breadth of internationalization speed. Although a high pace of internationalization can indeed result, up to a certain limit, in substantial benefits for the organization (Mohr \& Batsakis, 2017; Powell, 2013), we consider that this is limited to the geographic extent of the operational penetration. Past research has found a certain positive effect of internationalization speed on firm performance either because the focus was on the depth of internationalization speed, that is the speed of scaling existing foreign operations (Mohr \& Batsakis, 2017), or because the speed was considered in a single geographic context, such as the market entry in China (Powell, 2013).

First, we argue that firms which rapidly expand internationally with new entries in multiple foreign markets within a limited period of time will incur greater costs than their peers which follow a slower pace in their internationalization process. We contend that such costs will be mainly attributed to time compression diseconomies (Dierickx \& Cool, 1989), where an internationalizing firm suffers relatively higher costs due to the need to simultaneously develop and deploy its resources and capabilities at a faster pace across a wide number of foreign countries (Knott et al., 2003). Second, firms which decide to expand rapidly in new foreign markets will have to learn predominantly through trial and error, initially investing heavily on acquiring new knowledge and in the following years to reap the benefits of this learning process by applying it within these markets through penetrating with greater depth (Casillas \& Moreno-Menéndez, 2014; Nadolska \& Barkema, 2007). Firms that internationalize rapidly in multiple foreign countries might not have the opportunity to learn from their operational experience and errors and thus will not effectively absorb and apply this knowledge to new foreign markets. Third, the wider the breadth of internationalization the more likely the internationalizing firm to enter simultaneously in highly dissimilar market contexts (Mohr \& Batsakis, 2018). This in turn can result in increasing complexity and higher costs for the internationalizing firm. Extant research has shown that when the breadth of internationalization is high, the costs related to adding a new market to the MNE's portfolio will outweigh its benefits, thus leading to diminishing returns (Jain et al., 2019). We therefore conclude that a higher level of breadth of internationalization speed will be negatively related to firm performance.

Hypothesis 1: There is a negative relationship between the breadth of internationalization speed and firm performance.

\subsection{The Paradox of Concurrently Committing to Both Breadth and Depth of Internationalization Speed}

The ability of a firm to concurrently expand internationally in multiple dimensions contradicts past tradition (Johanson \& Vahlne, 1977, 2009) and renders such a strategy paradoxical. In the case of firm internationalization, we juxtapose two different dimensions of the process, namely the breadth and depth activities of rapid internationalization. The IB field does provide a context in which firms can concurrently commit to both breadth and depth activities (Luo \& Rui, 2009). For example, the seminal study by Zahra et al. (2000), in an attempt to explain the effect 
of internationalization process on firm technological learning, distinguish between breadth and depth of technological learning and explore the effect breadth and depth of technological learning have on firm performance. In another study, Nadkarni et al. (2011) examine the effect of mindsets on the early international performance of firms. In this process they identify and assess two mindsets; breadth mindset which relates to broad, diverse and heterogenous perspectives in an executive's mind and depth mindset which is associated with the degree of specialization and sophistication of an executive. In both studies, breadth and depth relate to the knowledge, learning and commitment of a firm or executive towards the internationalization process.

More recently, Vahlne and Johanson (2017) in an attempt to reflect on the evolution of their seminal work (i.e., Uppsala model) have noted that the process view of internationalization is contingent upon the successful interaction of stability and change, which in turn explains the paradox of considering exploitation and exploration as "mutually supportive, rather than competing" (Vahlne \& Johanson, 2017, p. 1089). Although rapid growth in breadth or depth may seem logical when each is considered in isolation, once juxtaposed they create tension and they do seem "irrational, inconsistent, and absurd" (Smith \& Lewis, 2011, p. 387). We argue that the pursuit of concurrent internationalization speed is paradoxical because its two dimensions (breadth and depth) are contradictory, interrelated, simultaneous and persistent (Pant \& Ramachandran, 2017). Contradictory, because the need to quickly expand in multiple new locations comes at the expense of penetrating more deeply in existing locations (Hutzschenreuter \& Harhoff, 2020), and therefore any strategic decisions managers make will eventually lead to trade-offs. Interrelated, as both strategic decisions use and fight for the same managerial and non-managerial resources of the firm (Penrose, 1959) for the same purpose of growing the firm internationally. This is mainly attributed to the limited financial and managerial resources firms have and the fact that they need to strategically prioritize and assess where these resources should be allocated or redeployed in order for the firm to achieve the best possible returns. Simultaneous, since decisions about the breadth of internationalization speed imply decisions for the depth of internationalization speed, and the opposite (Pant \& Ramachandran, 2017). For instance, rapid expansion in new foreign markets would require the deployment of experienced managerial resources that would otherwise be needed in existing locations to further penetrate in these markets. Finally, persistent, because decisions at a specific time do not preclude the reiterative need for future decisions (Smith \& Lewis, 2011). As an example, firms that decide to grow their market portfolio through entering in multiple foreign markets will need to keep on investing in these in order to ensure that a good level of commitment, engagement and learning within these markets is reached.

The assumed paradoxical perspective supports that successfully managing seemingly conflicting strategies (i.e., breadth and depth of internationalization speed in this study) eventually leads to increased performance (Lewis, 2000). This perspective differs from the non-paradoxical (conventional) approach which assumes that each of the two conflicting strategies should be considered in isolation. We consider two factors related to firm rapid internationalization to be critical in confirming the relevance and applicability of the paradoxical perspective. 
First, managerial resources from a paradoxical perspective assume that managers adopt a multitasking approach where they commit to both business expansion within existing markets and international expansion in new foreign markets. Such a paradoxical perspective assumes an improvement in managerial skills and capabilities to both sense new opportunities and replicate market knowledge to new countries. On the other hand, in a non-paradoxical perspective, managerial resources commit to single-tasking activities (either breadth or depth) which restrain the ability of key managers to learn quickly (Lewis et al., 2014) and improve their international business development capabilities. Second, learning in the paradoxical perspective relates to a dynamic and multifaceted process as both firms and managers concurrently learn from rapid expansion in existing and new markets (O'Grady \& Lane, 1996). However, when following a non-paradoxical perspective, learning in the rapidly internationalizing process is developed by focusing on a single activity each time. Therefore, the paradoxical perspective embraces simultaneity as a process, while the non-paradoxical perspective assumes a sequential (stepwise) approach. The former allows firms to develop multisided capabilities and innovative approaches, thus also allowing them to benefit from complementarities, while the latter is focused on financial discipline, rationality and embraces the existence of trade-offs.

The aforementioned suggests that firms adopting a paradox approach in their internationalization process by combining the two strategic dimensions of breadth and depth are capable of achieving comparatively higher firm performance. This appears to be in conflict with the time compression diseconomies theory (Dierickx \& Cool, 1989; Jiang et al., 2014; Vermeulen \& Barkema, 2002) which suggests that very high levels of internationalization speed result in subpar performance (GarcíaGarcía et al., 2017; Mohr \& Batsakis, 2017; Wagner, 2004; Yang et al., 2017). In our context, acceleration of learning through entering multiple countries in a short period of time (Mohr \& Batsakis, 2018) by simultaneously (and rapidly) scaling firm resources through market-seeking expansion can be particularly beneficial. Besides MNEs leveraging their existing capabilities through a deeper market penetration (i.e., depth of internationalization speed), they equally need to deploy resources in new markets (i.e., breadth of internationalization speed) from where they tap in new knowledge reservoirs which will help them learn, innovate and develop new-capabilities (Jiang et al., 2014; Kafouros et al., 2014). Empirical evidence shows that a firm's prior international experience diversity positively moderates (i.e., flattens) the inverted U-shaped relationship between internationalization speed and firm performance (García-García et al., 2017; Mohr \& Batsakis, 2017). However, the learning benefits stemming from the rapid expansion in many new countries (breadth) can be accompanied by substantial costs. These costs can be outweighed if the lessons learned from penetrating in new foreign markets can be also exploited by an increased depth in existing markets. This suggests that a rapid expansion in breadth has to be leveraged by an appropriate rate of expansion in existing markets (depth); a seemingly paradoxical strategy that has the potential of creating a dynamic equilibrium that enhances performance (Smith \& Lewis, 2011). We therefore hypothesize that firms which adopt an approach where they rapidly and simultaneously internationalize in both breadth and depth, will show high levels of firm performance. 
Hypothesis 2: Depth of internationalization speed positively moderates (alleviates) the negative relationship between breadth of internationalization speed and firm performance.

\subsection{The Moderating Role of CEO Characteristics}

In the previous section we drew on paradox theory and argued that concurrent internationalization speed is positively related to firm performance. More specifically, we contended that rapid internationalization in two paradoxical, yet interrelated elements, these of breadth and depth activities, can coexist and persist over time (Smith $\&$ Lewis, 2011). However, what are the characteristics of senior executives who can concurrently manage these paradoxical dimensions of internationalization speed in order to increase organizational performance? Smith and Lewis (2011, p. 392) in their seminal work, propose that "actors with cognitive and behavioral complexity and emotional equanimity are more likely to accept paradoxical tensions rather than respond defensively". Organizations in order to tackle this paradox need to draw on individual mindsets who will embrace paradoxical tensions and deliver in terms of making them harmonically coexist (Miron-Spektor et al., 2018).

We argue that such paradox mindsets can be senior executives (i.e., CEOs) who embrace and feel comfortable with paradoxical tensions. As an example, Wang et al. (2018) find that firms can better reconcile the paradox of short-term and long-term tensions that exist in the organization through the exercise of appropriate managerial skills, such as expertise, connectivity and empowering leadership, that altogether can effectively orchestrate this reconciliation. Similarly, the literature informs us that executives working in teams experiencing higher levels of cognitive conflict tend to produce higher-quality decision-making (Amason, 1996). Such individuals consider tensions as opportunities instead of threats (Lewis, 2000). Therefore, we draw on UE theory (Carpenter \& Geletkanycz, 2004; Hambrick \& Mason, 1984) and argue that CEOs with specific observable characteristics and merits can more efficiently organize and coordinate firm and managerial resources in times of extreme pressure. The logic behind applying UE theory is based on the assumption that senior executives (i.e., CEOs) who have a certain set of skills and professional background can better embrace and reconcile paradoxical tensions created as a result of concurrent internationalization speed.

Hence, we argue that senior executives can draw on their intuition and mental ability to view tensions as paradoxes rather than dilemmas (Costanzo \& Di Domenico, 2015; Zhang et al., 2017). In this manner they can have a deeper understanding of contradictory elements and reach out for more integrative solutions. Given that experiencing tensions is linked to heavy job demands (Perrewé et al., 2000) it can be argued that executives encountering very demanding tasks "will be forced to take mental shortcuts and fall back on what they have tried or seen work in the past" (Hambrick, 2007, p. 336). In other words, their decision-making will vastly reflect their backgrounds and personal characteristics. Accordingly, we expect that certain CEO dispositions, specifically CEO international experience and level of education, which serve as efficient proxies for constructs such as job knowledge, organizational 
socialization, and physical skills (Sturman, 2003), will moderate the relationship between concurrent internationalization speed and firm performance. Below, we present our logic leading to each hypothesis.

\subsubsection{The Moderating Role of CEO International Experience}

Retail firms adopting a high pace of concurrent internationalization are likely to incur greater costs in terms of identifying, screening and assessing information that is required in order for them to perform well. Such information is known to be held by internationally experienced CEOs, who in general have developed relevant skills and capabilities throughout their international career and work assignment (Carpenter et al., 2001; Daily et al., 2000; Le \& Kroll, 2017), as well as their unique capability to draw on their long-term memory and utilize complex configurations of knowledge (Rost \& Osterloh, 2010). Since firm performance depends on information and knowledge that is more likely to be found among internationally experienced executives who are more sensitive to opportunities and faster in retrieving information related to international expansion (Nielsen \& Nielsen, 2011; Tihanyi et al., 2000), we expect that retail firms with a high concurrent internationalization speed will perform better if they have on board internationally experienced CEOs. Internationally experienced senior executives have more chances of demonstrating the necessary skills and international network (Fredberg, 2014) that will allow them to reach foreign markets quickly after a firm's inception (Reuber \& Fischer, 1997). Retail firms which choose to expand quickly in foreign markets benefit from the presence of an internationally experienced team of senior executives (Mohr \& Batsakis, 2019).

Conversely, when CEO international experience is low, retail firms will not be as effective in terms of applying complex configurations in the internationalization process, such as this of concurrent internationalization speed. Limited international experience at the executive level will not bring the so much needed set of valuable and rare knowledge and skills (Bouquet et al., 2009; Hsu et al., 2013), as tapping into idiosyncratic foreign markets and location-bound networks and information will be a considerably more demanding process. This moderating role of CEO international experience on concurrent internationalization speed is summarized in the following hypothesis.

Hypothesis 3: CEO international experience will strengthen the positive relationship between concurrent internationalization speed (i.e., breadth and depth of internationalization speed) and firm performance.

\subsubsection{The Moderating Role of CEO Education}

The relationship between concurrent internationalization speed and firm performance is also influenced by the level of CEO education. Retail firms which expand at a high concurrent internationalization speed are in need of utilizing and tapping into managerial knowledge which will help them take fast and educated decisions when it comes to internationalization, which in turn can have a positive 
effect on firm performance (Hsu et al., 2013). Such knowledge can be linked to the level of education of a senior executive.

First, education has been in general associated with an increase in the ability to absorb new ideas and an increase in cognitive complexity (Herrmann \& Datta, 2005). This is particularly important in our context since concurrent internationalization speed does indicate a greater push for both greater geographical diversity and ability to augment business activity of existing operations. Accordingly, a CEO's education level is more likely to be a performance facilitator for retail firms which rapidly internationalize in two dimensions, because it offers value-added knowledge and information which is particularly important in resource-demanding and time-compressed processes, such as this of concurrent internationalization speed. Second, CEOs with a high level of education are characterized by increased ability to dealing with complex problems (Goll et al., 2007), which in turn makes them more capable when coping with demanding and multisided tasks in the context of rapid internationalization. Third, the corporate finance literature has identified a positive link between CEO education and rapid adjustment of the firm's capital structure (Frank \& Goyal, 2007), its ability to raise capital (Gounopoulos et al., 2020) and the propensity to adopt more innovative business models to improve its performance (King et al., 2016). These CEO education-related capabilities (i.e., rapid adjustment, easier access to capital, innovativeness) are likely to enhance firm performance by effectively managing firm rapid expansion in both new and existing markets (Casillas \& MorenoMenéndez, 2014; Makino et al., 2002; Mohr \& Batsakis, 2018).

In contrast, when the level of CEO education is low, retail firms will lack access to important competences necessary for a rapid internationalization strategy, such as information processing capacity. First, a low level of CEO education is linked with a lower ability to tolerate ambiguity, which is a required skill when rapidly implementing an international expansion strategy and can negatively impact the returns associated to such a strategy. Second, a low level of CEO education can lead to diminishing levels of strategic change as reflected by limited changes in diversification strategy (Wiersema \& Bantel, 1992). This in turn can impose restrictions to the firm's ability to rapidly expand in new and existing foreign markets and put strains on its financial performance. Therefore, we hypothesise that CEO education can have a positive effect on achieving rapid internationalization in a concurrent fashion, since education enables these executives to deal with the associated complexity and ambiguity, and to bring innovation and strategic change to their organizations. This moderating role of CEO education on concurrent internationalization speed is summarized by the following hypothesis.

Hypothesis 4: CEO education will strengthen the positive relationship between concurrent internationalization speed (i.e., breadth and depth of internationalization speed) and firm performance.

Overall, our study tests four hypotheses. Figure 1 presents the conceptual model of our study illustrating the contingent effect of concurrent internationalization speed on firm performance. 


\section{Conceptual model}

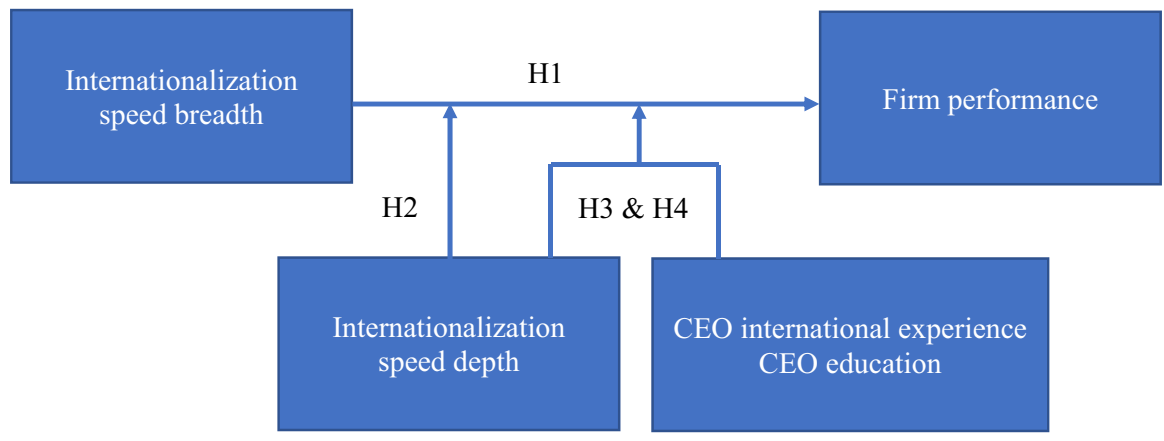

Fig. 1 Conceptual model

\section{Data and Methods}

\subsection{Research Setting, Data Collection Process and Sample Characteristics}

Our study's research context is the retail sector. We consider the retail sector to be a proper setting to test our research questions for a number of reasons. First, the retail sector allows us to focus on the market-seeking, horizontal international expansion of firms, thus allowing us to eliminate the potential effect of different expansion motives. Second, the retail sector is a particularly good fit to test our research question related to speed of internationalization. Anecdotal evidence suggests that service-sector firms in general and retailers in particular (e.g., Zara, Tesco), due to the increasing time-based competition they are confronted with, are more experienced and adaptive to practices related to fast expansion (Coe \& Wrigley, 2007; Ghemawat \& Nueno, 2006). This automatically creates the right conditions to test such a research question to a more homogenous group of firms. Third, service sector firms remain under-studied in IB research in contrast to manufacturing firms, although services account for a larger share of the world's GDP than manufacturing (Kundu \& Lahiri, 2015; Pogrebnyakov \& Maitland, 2011).

Our research is based on the horizontal market-seeking international expansion of some of the largest retail MNEs with international presence in one or more foreign markets during the 10-year period 2003-2012. As previously stated, examination of this period allows us to test our hypotheses under economic stability and economic crisis conditions, as it includes the global financial crisis. This is of particular importance for our study. Although retrenchment is a widely observable response during crises (Bruton et al., 2003; Wenzel et al., 2020), yet the associated reduction of business scope leads to the loss of synergistic effects and obstructs the achievement of economies of scale (de Figueiredo Jr et al., 2019). This is of particular relevance to retail MNEs who greatly benefit from the economies of scale achieved through market-seeking activities.

Since there is a large number of retailers with no international operations, we opt for all retailers with international operations that were listed on one or more 
of the following three company rankings: (i) PlanetRetail's Top Global 250 Retailers (2012); (ii) Deloitte's Top 250 Global Retailers (Deloitte, 2011); and (iii) UNCTAD's ranking list of the top 100 transnational corporations (UNCTAD, 2012). The amalgamation of all retailers with international operations on these rankings resulted in a list consisting of a total of 189 large internationally operating retailers, including firms, such as, for instance, Carrefour, Tesco, Marks and Spencer, Home Depot, Best Buy, The Gap, and Inditex, among others. For these firms, we extracted data for a 10-year period (2003-2012) from the PlanetRetail and ORBIS databases. Given that on several occasions, ORBIS provided no or very limited data on some of the 189 retailers, the initial sample was reduced to 144 firms. We next complemented our firm-level data with information gathered on CEO observable characteristics. More specifically, we subsequently gathered data on CEO characteristics from retailers' annual reports. We measured all CEO variables for each firm-year observation. If an annual report did not provide data on CEO characteristics, we manually collected this information from corporate websites, Bloomberg's Businessweek, Forbes, LinkedIn, Reuters, and similar sources. Our final sample consists of 91 retail firms and 647 firm/year observations, which generate revenues in one or more retail segments, including grocery, electricals and office, food service, clothing and footwear, leisure and entertainment, health and beauty, and home and garden. Out of the 91 retail firms, the vast majority originate predominantly from developed markets, while most of these firms are headquartered in the US and Canada (47.25\%) and Europe (34.07\%).

\subsection{Measures}

In line with previous studies in the services sector (e.g., Capar \& Kotabe, 2003; Contractor et al., 2003), our dependent variable, firm performance, is measured as the ratio of net income to total sales (ROS). This performance measure is particularly relevant to the retail sector, given of course the market-seeking, horizontal international expansion of these firms (Mohr et al., 2014), while it is relatively preferable to other performance measures, since it is not spurious to accounting-related issues occurring due to exchange rate fluctuations and cross-country differences in regards to asset depreciation rules (Geringer et al., 1989).

To test our main hypothesis on the effect of concurrent internationalization speed on form performance we make use of two key variables; internationalization speed breadth and internationalization speed depth. Both variables are proxied from established constructs of internationalization speed in the literature of temporal internationalization, as well as in the literature with a retail-specific focus. We thus consider that both independent variables are appropriate for the retail context of our study. First, as a proxy for the temporal breadth activity of internationalization, we introduce the measure of internationalization speed breadth. For this measure, we consider the number of new countries a retail firm has entered during an internationalization episode, i.e., a one (calendar) year time window during which a firm has expanded into at least one new overseas market (Mohr \& Batsakis, 2018). We argue that this proxy reflects on the learning endeavours of the retail firm which are 
better accumulated by the wider presence in multiple locations and exposure to different country settings. This measure has been used previously in a retail-specific context. Similar to the previous variable, and in order to normalize the distribution of the variable, a logarithmic transformation was taken. Second, we measure the depth of internationalization speed as the average number of foreign outlets divided by the number of years since the firm's first international expansion (Batsakis \& Mohr, 2017; Chang \& Rhee, 2011; Jain et al., 2019; Vermeulen \& Barkema, 2002). Extant literature has used this measure, also in a retail-specific context, to capture the speed by which firms scale their operations in a foreign market and is particularly suited to studying the internationalization of large MNEs (Chetty et al., 2014). In line with March (1991), we consider that this temporal dimension of internationalization reflects on the retail MNE's capability to rapidly extend its competencies in both new and existing markets through opening up new retail stores. In order to normalize the distribution of the variable, a logarithmic transformation was taken.

In terms of operationalization, we treat the combined effect (i.e., interaction effect) of internationalization speed depth and internationalization speed breadth as an effective way to assess the extent of adoption of rapid concurrent internationalization speed. In a similar fashion, extant research has repeatedly used the interaction effect between breadth and depth as a predictive variable of a firm performance outcome. For example, Hsu and Boggs (Hsu \& Boggs, 2003) decompose internationalization to scope and scale and test their interaction effect to assess the differential effect of different forms of internationalization on firm performance. In the same vein, Katila and Ahuja (2002) use the interaction effect of search depth and search breadth to assess the distinct effects of knowledge depth and scope on firm innovative performance. Similarly, Li et al. (2013) employ the interaction of breadth and depth of internationalization to test their combinative effect on firm performance. Finally, Bercovitz and Mitchell (2007) employ the interaction effect of product scale and produce scope to assess long-term firm survival. Following the same logic, we argue that a high value of the interaction between internationalization speed depth and internationalization speed breadth depicts a high level of a firm's commitment towards both breadth and depth activities of the rapid internationalization process. Our key variables are to a great extent equally distributed throughout the 10-year period as we do not observe any substantial deviations in terms of internationalization speed between years (i.e., internationalization events are not unequally concentrated between years).

We measure our moderating variables as follows. Following prior research (e.g., Hsu et al., 2013; Hutzschenreuter \& Horstkotte, 2013; Lee \& Park, 2008), we measure CEO international experience by utilizing three proxies of CEOs' international exposure. Specifically, we calculate the average of three dummy variables reflecting (a) international working experience (Herrmann \& Datta, 2005; Hsu et al., 2013); (b) international education experience (Herrmann \& Datta, 2005); (c) whether the CEO was born in a foreign country (Hutzschenreuter \& Horstkotte, 2013). We thus utilized these three proxies to assess the international experience of CEOs. In order to confirm the validity of this composite measure, we ran a confirmatory factor analysis which revealed that the single measure of CEO international experience produces a single factor with an eigenvalue of 1.876 , explaining $62.55 \%$ of 
variance, Cronbach's alpha equalling 0.65, Composite Reliability equalling 0.83, and Average Variance Extracted equalling 0.63. Following prior research (Datta \& Rajagopalan, 1998; Zhang \& Rajagopalan, 2010) we measure CEO education via constructing a seven-point scale variable and based on the CEOs' highest degree earned (i.e., $1=$ high school, $2=$ some college, $3=$ undergraduate degree, $4=$ some graduate school, $5=$ master's degree, $6=$ attended a doctoral program, and $7=$ doctoral degree).

Finally, we incorporate a number of control variables to account for additional CEO-, country- and firm-level factors that may potentially affect firm performance. $C E O$ age is measured by counting the years since a CEO was born. We measure CEO tenure by counting the number of years a CEO had been in office (Henderson et al., 2006; Zhang \& Rajagopalan, 2010; Zhang \& Wiersema, 2009). Following past studies with research in CEO origin (Zhang \& Rajagopalan, 2010) we introduce the outside CEO variable which takes the code 1 if the CEO was an outside CEO who had firm tenure of less than two years when s/he assumed the CEO position and 0 otherwise.

We measure firms' financial leverage by including the firm's liquidity ratio which is measured as the sum of cash equivalents, marketable securities and accounts receivables divided by the current liabilities of the firm. Firm age is measured by the year of observation minus year of inception (Chang et al., 2013). Firm size is measured using the natural logarithm of firms' total sales in line with past research (Carpenter \& Sanders, 2004). ${ }^{2}$ Firm international experience was measured as the total number of years a firm has operated in each different foreign country, reflecting both the depth and breadth of firms' accumulated international experience (Casillas \& Moreno-Menéndez, 2014; Mohr et al., 2018). We measure firms' intangible assets in line with prior research by computing the ratio of intangible assets to total assets (Chang et al., 2013). We also include firm geographic scope, which is measured by the total number of foreign countries in which the MNE has established at least one outlet (Vermeulen \& Barkema, 2002).

With regard to country-level controls, we account for the effect of cultural distance. Specifically, we use the measure of added cultural distance which represents the distance between a newly entered country and all countries in which a firm already operates and then taking the smallest of these distances (Hutzschenreuter \& Voll, 2008; Hutzschenreuter et al., 2014; Jain et al., 2019). To calculate this variable, we use the formula developed by Kogut and Singh (1988) and the cultural values reported by Hofstede (2001). Further, we control for home market size by taking the natural logarithm of the home country's gross domestic product (GDP). Finally, we introduce a dummy variable to control for the post-2008 financial crisis which has negatively affected global trade flows in general and the retail sector in particular. This variable takes the value 1 if the respective year is after the year 2008 and 0 otherwise.

\footnotetext{
${ }^{2}$ As an alternative measure for firm size, we also used the natural logarithm of firms' total assets (Grant et al., 1988). The results are very consistent.
} 


\subsection{Estimation Method}

Our data are structured as a pooled time-series cross-section. The majority of our variables are in time-series formation (i.e., they change over time); however, we control for possible unobserved heterogeneity (Wooldridge, 2010) by incorporating several dummy variables that lack a time dimension (e.g., retail firms' sector classification). We use a lagged variable approach (1-year lag) between the dependent variable and the independent, moderating and control variables. As such, values for our dependent variable cover the years 2004-2012, whereas values for the independent, moderating and control variables cover the years 2003-2011.

A common issue affecting panel data in general, and our dataset in particular, is the potential of the dependent variable being autocorrelated within a panel, and as a result the autocorrelation coefficient is likely to be different across panels. In general terms, the adoption of a generalized least squares (GLS) estimator provides efficient estimates for such a dataset. However, after conducting several diagnostic tests we observed that heteroskedasticity and autocorrelation (via employing the White test and the Wooldridge test, respectively) are issues potentially biasing the validity of our estimates. For that reason, also following prior studies (Mohr \& Batsakis, 2017; Strike et al., 2006; Vaaler, 2011; Zhang \& Rajagopalan, 2010), we employ a feasible generalized least squares (FGLS) estimator which corrects for heteroskedasticity and panel-specific autocorrelation, via using the option of first-order panel-specific autocorrelation (psar1).

\section{Results}

Table 1 presents descriptive statistics and pairwise correlations. Before we proceed to the regression analysis, we first need to make sure that our sample does not suffer from potential multicollinearity issues. Generally, the rule of thumb indicates that correlation coefficients with values higher than the threshold of 0.70 are likely to be problematic. In addition, our dataset also contains interaction effects, which are frequently associated with possible presence of multicollinearity. In order to deal with this issue, we mean-center the respective variables (Aiken \& West, 1991). Also, we compute the variance inflation factor (VIF) statistics which indicate the absence of multicollinearity in all our models, as the highest VIF score is below the threshold of 10.0, which is one of the most common cutoff points for the possible presence of multicollinearity.

Table 2 presents the FGLS regression estimates predicting the contingent effect of internationalization speed on firm performance (ROS). In hypothesis 1 we argued for a negative effect of internationalization speed breadth on firm performance. The results (Model 1, Table 2) show that the coefficient of the term of internationalization speed breadth is negative and statistically significant $(\beta=-0.255, p=0.020)$, providing support for our first hypothesis.

In hypothesis 2 we argued for a positive effect of the aforementioned interaction on firm performance. Specifically, we argued that the interaction between internationalization speed breadth and internationalization speed depth will be positive, 


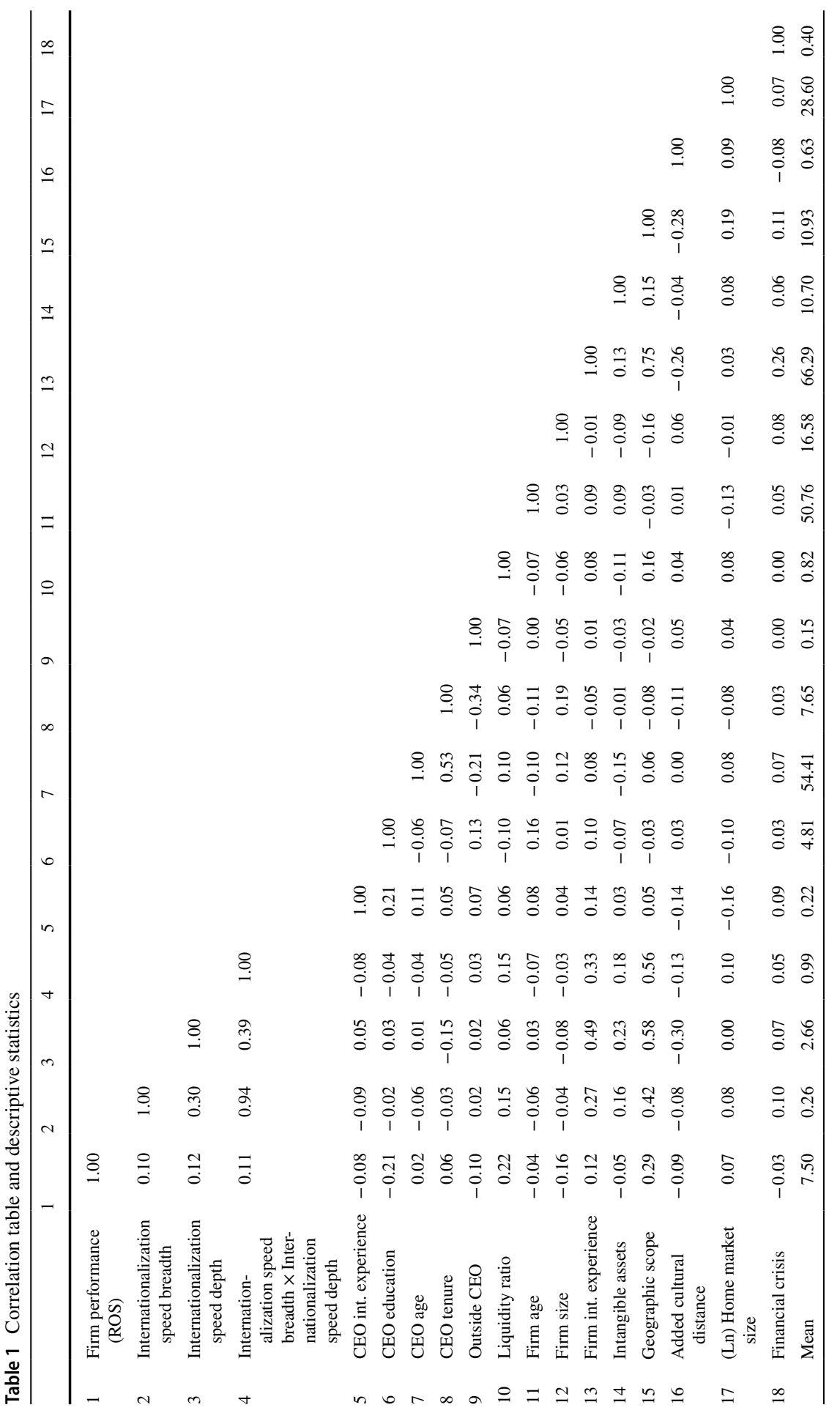




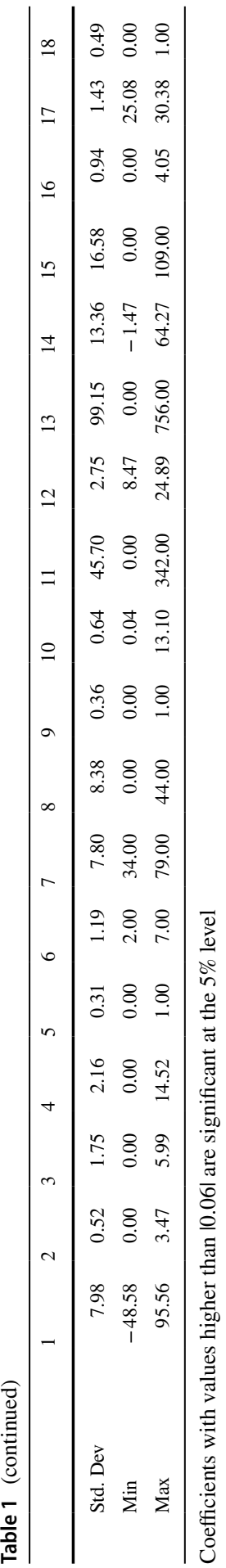


Table 2 Cross-sectional time-series FGLS regression on firm performance (ROS)

\begin{tabular}{|c|c|c|c|c|c|c|c|c|}
\hline & \multicolumn{2}{|l|}{ Model 1} & \multicolumn{2}{|l|}{ Model 2} & \multicolumn{2}{|l|}{ Model 3} & \multicolumn{2}{|l|}{ Model 4} \\
\hline & Coef. & s.e. & Coef. & s.e. & Coef. & s.e. & Coef. & s.e. \\
\hline $\begin{array}{l}\text { CEO international } \\
\text { experience }\end{array}$ & $-1.294^{* * *}$ & $(0.488)$ & $-1.049 * *$ & $(0.461)$ & -0.601 & $(0.600)$ & $-1.009^{* *}$ & $(0.471)$ \\
\hline CEO education & -0.171 & $(0.107)$ & -0.126 & $(0.106)$ & -0.158 & $(0.104)$ & 0.169 & $(0.237)$ \\
\hline CEO age & $-0.034 *$ & $(0.020)$ & -0.026 & $(0.019)$ & -0.016 & $(0.019)$ & -0.013 & $(0.020)$ \\
\hline CEO tenure & 0.012 & $(0.024)$ & 0.009 & $(0.023)$ & -0.009 & $(0.020)$ & -0.008 & $(0.023)$ \\
\hline Outside CEO & 0.085 & $(0.221)$ & 0.107 & $(0.211)$ & 0.077 & $(0.206)$ & 0.161 & $(0.221)$ \\
\hline Liquidity ratio & $1.717 * * *$ & $(0.300)$ & $1.638 * * *$ & $(0.302)$ & $1.663^{* * * *}$ & $(0.300)$ & $1.612 * * *$ & $(0.305)$ \\
\hline Firm age & $0.015^{* * * *}$ & $(0.004)$ & $0.017 * * *$ & $(0.004)$ & $0.017 * * *$ & $(0.003)$ & $0.015^{* * * *}$ & $(0.004)$ \\
\hline Firm size & 0.119 & $(0.086)$ & 0.096 & $(0.087)$ & 0.101 & $(0.087)$ & 0.113 & $(0.088)$ \\
\hline Firm int. experience & $-0.012 * * *$ & $(0.002)$ & $-0.011^{* * *}$ & $(0.002)$ & $-0.011 * * *$ & $(0.002)$ & $-0.011^{* * *}$ & $(0.002)$ \\
\hline Intangible assets & $-0.057 * * *$ & $(0.013)$ & $-0.057 * * *$ & $(0.012)$ & $-0.054 * * *$ & $(0.011)$ & $-0.052 * * *$ & $(0.012)$ \\
\hline Geographic scope & $0.105^{* * * *}$ & $(0.016)$ & $0.090 * * *$ & $(0.017)$ & $0.075^{* * *} *$ & $(0.017)$ & $0.080^{* * * *}$ & $(0.017)$ \\
\hline $\begin{array}{l}\text { Added cultural } \\
\text { distance }\end{array}$ & -0.048 & $(0.118)$ & -0.061 & $(0.116)$ & -0.070 & $(0.115)$ & -0.088 & $(0.122)$ \\
\hline $\begin{array}{l}\text { (Ln) Home market } \\
\text { size }\end{array}$ & $-0.365^{* *}$ & $(0.149)$ & $-0.310^{* *}$ & $(0.151)$ & -0.225 & $(0.147)$ & $-0.275^{*}$ & $(0.153)$ \\
\hline Financial crisis & $0.563^{* *}$ & $(0.269)$ & $0.531 * *$ & $(0.265)$ & $0.600^{* *}$ & $(0.259)$ & $0.641 * *$ & $(0.277)$ \\
\hline $\begin{array}{l}\text { Internationalization } \\
\text { speed breadth } \\
(H 1)\end{array}$ & $-0.255^{* *}$ & $(0.109)$ & $-0.791 * * *$ & $(0.298)$ & $-0.592^{* *}$ & $(0.334)$ & $2.695^{* *}$ & (1.389) \\
\hline $\begin{array}{l}\text { Internationalization } \\
\text { speed depth }\end{array}$ & 0.102 & $(0.084)$ & 0.103 & $(0.083)$ & $0.186^{*}$ & $(0.097)$ & $0.614^{* *}$ & $(0.290)$ \\
\hline $\begin{array}{l}\text { Internation- } \\
\text { alization speed } \\
\text { breadth } \times \text { Inter- } \\
\text { nationalization } \\
\text { speed depth }(\mathrm{H} 2)\end{array}$ & & & $0.145^{* *}$ & $(0.073)$ & $0.080^{*}$ & $(0.079)$ & $-0.922 * * *$ & $(0.370)$ \\
\hline $\begin{array}{l}\text { Internation- } \\
\text { alization speed } \\
\text { breadth } \times \text { Inter- } \\
\text { nation- } \\
\text { alization speed } \\
\text { depth } \times \text { CEO } \\
\text { international } \\
\text { experience }(H 3)\end{array}$ & & & & & $0.557^{* *}$ & $(0.315)$ & & \\
\hline $\begin{array}{l}\text { Internation- } \\
\text { alization speed } \\
\text { breadth } \times \text { Inter- } \\
\text { nation- } \\
\text { alization speed } \\
\text { depth } \times \text { CEO } \\
\text { education }(H 4)\end{array}$ & & & & & & & $0.217^{* * *}$ & $(0.075)$ \\
\hline Constant & $18.150^{* * *}$ & $(4.081)$ & $16.238 * * *$ & $(4.149)$ & $13.366^{* * * *}$ & (4.049) & $13.103 * * *$ & (4.332) \\
\hline Wald $\mathrm{Chi}^{2}$ & $2129.55^{* * *}$ & & $2909.80 * * *$ & & $3078.33 * * *$ & & $2405.08 * * *$ & \\
\hline
\end{tabular}

FGLS estimator that is robust to first-order panel-specific autocorrelation (AR1) and heteroskedasticity; $* \mathrm{p}<0.10 ; * * \mathrm{p}<0.05 ; * * * \mathrm{p}<0.01$; one-tailed tests for independent and moderating variables; two-tailed tests for controls; Model 3 includes the interaction terms of Internationalization speed breadth $\times$ CEO international experience, Internationalization speed depth $\times$ CEO international experience; Model 4 includes the interaction terms of Internationalization speed breadth $\times$ CEO education, Internationalization speed depth $\times$ CEO education; The estimates are not reported for brevity; Year and industry dummies are included in all models but their estimates are not reported for brevity; all variables are lagged 1 year; Number of observations $=647$; Number of firms $=91$ 
thus we expect the initially negative relationship between internationalization speed breadth and firm performance to attenuate and turn into a positive one. As may be observed, and in alignment with this hypothesis' expectations, the coefficient for the term of the interaction term between internationalization speed breadth and internationalization speed depth (Model 2, Table 2) is positive and statistically significant $(\beta=0.202, p=0.003)$, providing support for our second hypothesis. To better understand the aforementioned effect, we proceed to the graphic illustration of the predictive margins of the estimated coefficient. Figure 2 shows that firms with high internationalization speed depth experiencing a high level of internationalization speed breadth perform better as they see an increase in their performance. ${ }^{3}$ On contrary, firms with low internationalization speed depth experiencing a high level of internationalization speed breadth see a substantial decrease in their performance.

With regard to hypothesis 3, we argued that CEO international experience will strengthen the positive relationship between the interaction of internationalization speed breadth and internationalization speed depth (concurrent internationalization speed) and firm performance, in a way that firm performance will increase at high levels of concurrent internationalization speed. The results of Model 3 in Table 2 provide support for hypothesis 3, since the interaction term of concurrent internationalization speed and CEO international experience (i.e., triple interaction) is positive and statistically significant $(\beta=0.557, p=0.038)$. This result indicates that the moderating effect of CEO international experience further improves the positive relationship between concurrent internationalization speed and firm performance. We thus conclude that hypothesis 3 is supported. In an attempt to better understand the moderating effect of CEO international experience, and in order to infer some practical implications from this relationship, we present the graphic illustration of the predictive margins of this relationship. Figure 3 shows that for high levels of CEO international experience and internationalization speed depth, the relationship between internationalization speed breadth and firm performance improves substantially. Specifically, the marginal effect on firm performance is positive, while for the rest of the cases the marginal effect is negative.

In hypothesis 4, we argued and predicted that CEO education will positively moderate the relationship between concurrent internationalization speed and firm performance, in a way that firm performance will be higher at high levels of all three variables (i.e., CEO education, internationalization speed breadth and internationalization speed depth). Specifically, the coefficient of the three-way interaction term (Model 4, Table 2) is positive and statistically significant $(\beta=0.217, \mathrm{p}=0.00185)$. We thus conclude that our results support hypothesis 4 . Figure 4 shows that for high levels of CEO education and internationalization speed depth, the relationship between internationalization speed breadth and firm performance improves substantially. Specifically, the marginal effect on firm performance is positive, also having the highest marginal effect on average.

\footnotetext{
${ }^{3}$ In order to distinguish between low and high values of our independent variables and moderators, we follow prior research and use percentiles (low $=25 \%$, high $=75 \%$ ) as a cut-off point (Smit et al., 2017; Yang et al., 2012).
} 


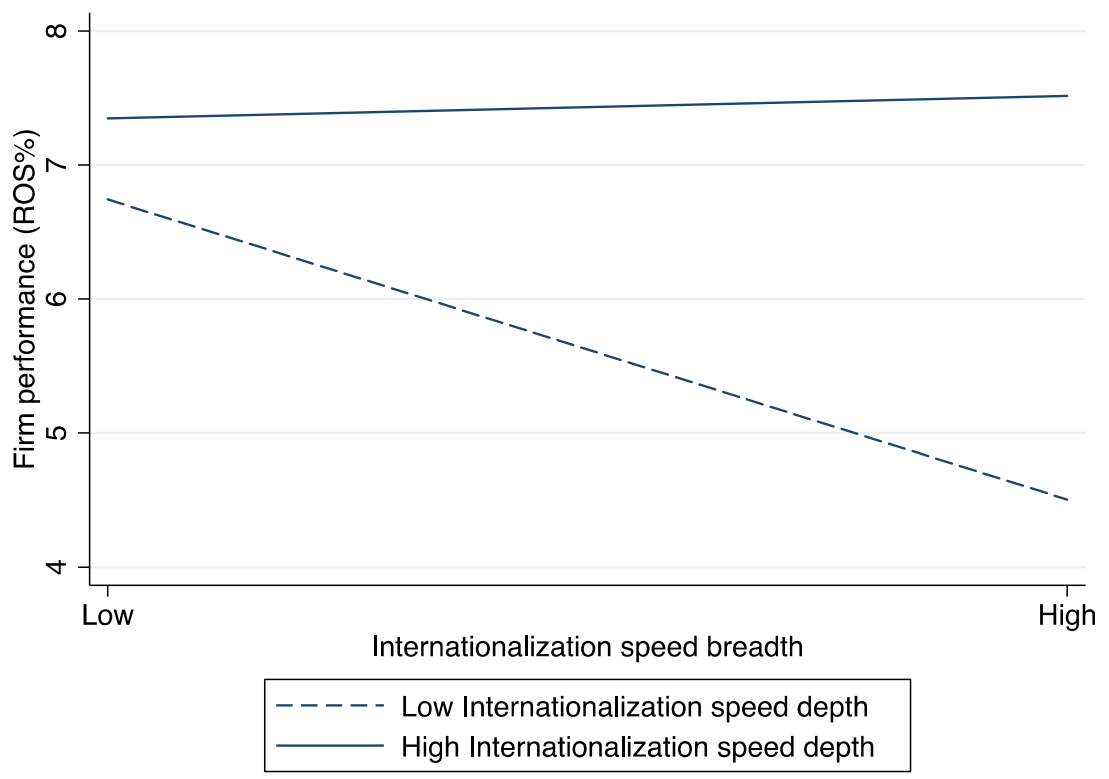

Fig. 2 The interaction effect of internationalization speed breadth and internationalization speed depth on firm performance (ROS)

\subsection{Robustness Tests}

In order to test the sensitivity of our results we proceed to some further analyses where we incorporate alternative variables or restrict the sample's observations. First, given the nature of our independent (internationalization speed breadth) and moderating variable (internationalization speed depth), there are cases of extreme values (outliers) on the upper level that might create some noise in the estimation of our models. For that reason, we decided to remove the upper $1 \%$ of their values and then re-estimate our models. After removing these outliers, the results remained very consistent, proving that the original sample is robust regardless the presence of some inflated values of these key variables. Table 3 (Appendix) reports the results. These are consistent with the results reported in Table 2.

Second, given the fact that one of the CEO-related moderating variables is a composite measure, being assessed and calculated based on three elements of CEO international experience, we decide to break down this composite measure to three binary variables (CEO born abroad, CEO educated abroad, CEO worked abroad). Although the relative reliability score indicates that the composite measure of CEO international experience is reliable, in line with extant research (Piaskowska \& Trojanowski, 2014) we explore whether some elements of the construct are relatively more or less efficient in explaining the relationship between concurrent internationalization 


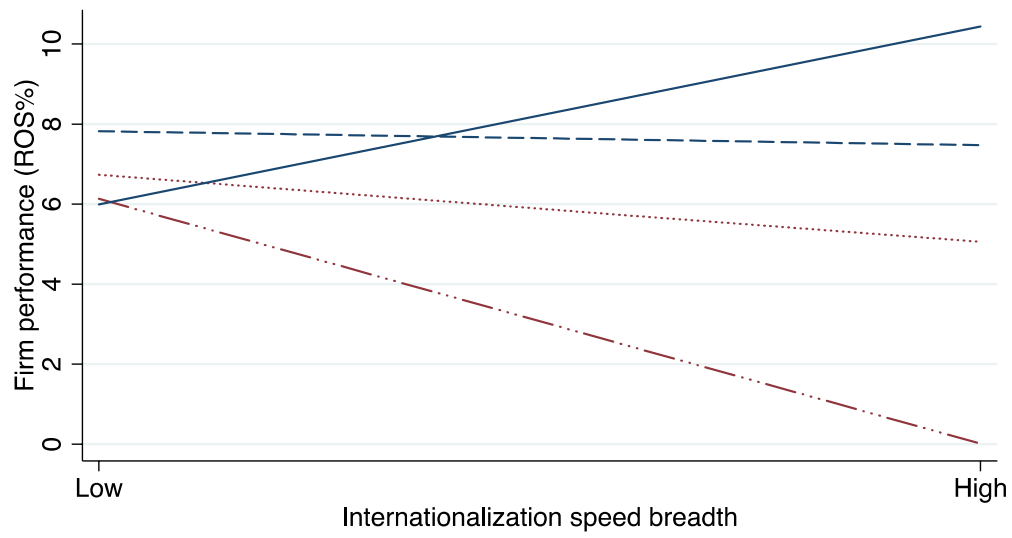

Low internationalization speed depth, Low CEO Int. experience $-\cdots-$ Low internationalization speed depth, High CEO Int. experience
---- High internationalization speed depth, Low CEO Int. experience
High internationalization speed depth, High CEO Int. experience

Fig. 3 The moderating effect of CEO international experience on the relationship between internationalization speed breadth and internationalization speed depth and firm performance (ROS)

speed and firm performance. The results show that two out of three elements (CEO educated abroad and CEO worked abroad) have a positive and significant moderating effect on the relationship between concurrent internationalization speed and firm performance. Overall, these results provide further support for the applicability and reliability of the CEO international experience composite measure, while we understand even better the importance of CEO professional and educational experience, as far as the international exposure of a manager is concerned. Table 4 (Appendix) presents the results.

Third, although our independent variable's operationalization (i.e., the interaction of internationalization speed breadth and internationalization speed depth) is different from these of extant studies on the performance effects of internationalization speed, we considered that since a large number of recent empirical studies find a curvilinear effect between internationalization speed and firm performance (see for example, García-García et al., 2017; Hilmersson \& Johanson, 2016; Mohr \& Batsakis, 2017; Powell, 2013; Wagner, 2004; Yang et al., 2017) we should also consider adding the quadratic term of the interaction term (concurrent internationalization speed) in our model. However, in our case the coefficient of the quadratic terms of the interaction was not statistically significant. Therefore, we are in position to confirm the initial linear specification. The estimates following the quadratic specification can be found under Table 5 (Appendix). 


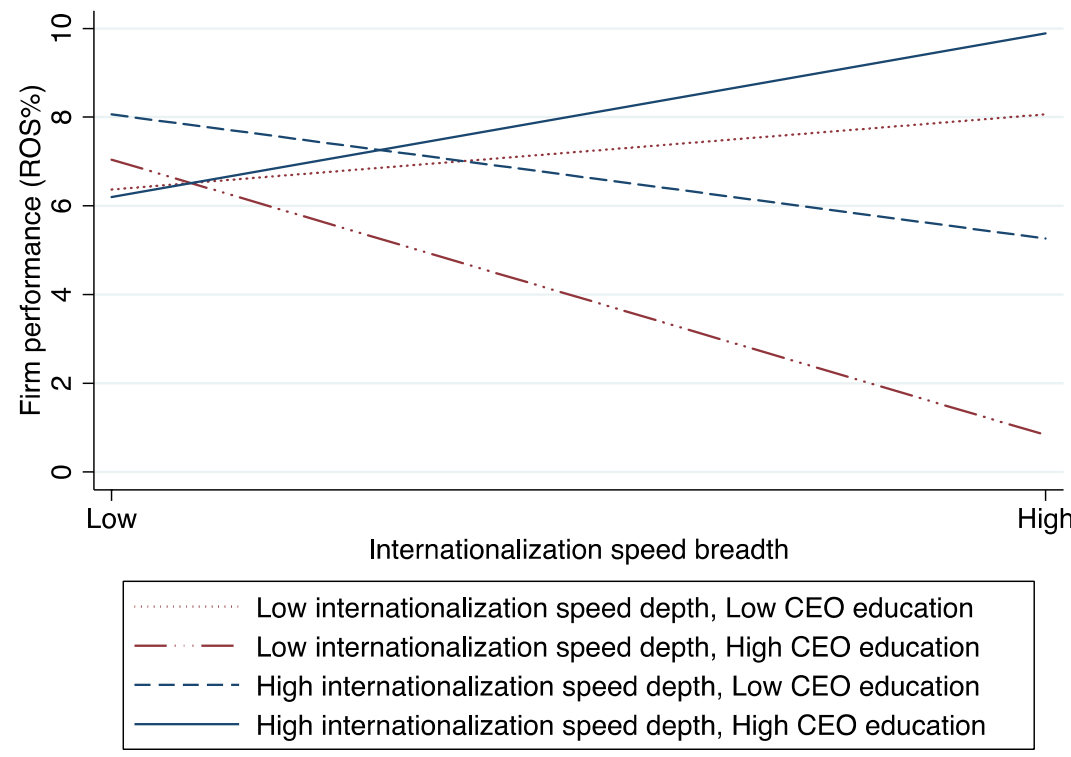

Fig. 4 The moderating effect of CEO education on the relationship between internationalization speed breadth and internationalization speed depth and firm performance (ROS)

\subsection{Accounting for the Impact of the 2008 Financial Crisis}

Given that the time context of our research falls within the period of the global financial crisis (i.e., the years after 2008), as well as considering that the retail sector has been heavily affected by the crisis, we proceed to a sensitivity analysis to assess whether our results are robust both in the pre-crisis and during-crisis period. ${ }^{4}$ The descriptive statistics initially confirm this assumption as the average firm performance for the period before and during crisis is $7.72 \%$ and $7.17 \%$ respectively (i.e., a decrease of $7.12 \%$ ). However, when it comes to internationalization speed, the statistics reveal that retailers have on average expanded faster internationally during crisis (we find an average increase of $23.07 \%$ in internationalization speed breadth as well as an average increase of $8.99 \%$ in internationalization speed depth). Our subsample analysis in the pre-crisis period, provides clear evidence that the paradox of concurrent internationalization speed is strong, since the estimates for that period are very consistent with the main findings (Table 6 in the Appendix). However, the subsample analysis for the during-crisis period shows that the levels of significance for the three interaction effects drop (Table 7 in the Appendix).

\footnotetext{
${ }^{4}$ We would like to thank one of the anonymous reviewers for stressing the importance of assessing the impact of the 2008 financial crisis.
} 


\section{Discussion}

In this paper we revisited the link between internationalization speed and firm performance. Extant research has been heavily drawing on the incremental internationalization literature (e.g., Barkema \& Drogendijk, 2007; Johanson \& Vahlne, 1977) to explain this phenomenon. In this study we drew on the paradox perspective and argued that firms can increase their performance by rapidly growing their international presence concurrently by breadth and depth. Our examination of retail MNEs demonstrates, as hypothesized, that a positive relationship exists between the interaction of the two dimensions of internationalization speed (breadth and depth of internationalization speed) and firm performance. This suggests that while indeed incremental internationalization is a sensible approach as has been repeatedly demonstrated (Johanson \& Vahlne, 1977, 2009) and also confirmed in our base hypothesis (hypothesis 1), the adoption of a concurrent rapid internationalization strategy also leads to high levels of financial performance (as confirmed in hypothesis 2).

Our investigation on concurrent internationalization speed and firm performance did proceed in more depth and sought to identify CEO characteristics that are linked with embracing the underlying paradoxical tensions and lead the firm to superior levels of performance (Heracleous \& Wirtz, 2014). Executives who better manage to successfully operate in extremely challenging circumstances, such as in the case of concurrent internationalization speed, do share similar characteristics, such as international experience and a rich educational background. These characteristics stress the value of CEO international experience, as experiential knowledge can trigger their mental abilities to draw on their longterm memory and established international network in order to handle complex situations in the internationalization process. Similarly, well-educated CEOs can be successful when it comes to rapidly expanding in two international dimensions (i.e., breadth and depth activities) at the same time. The findings confirm that the mental capacity of such CEOs can help them quickly process relevant information and achieve strategic change in a context characterized by increased complexity. Overall, our findings are consistent with the call that we need paradox savvy executives (i.e., executives with increased mental capacity cultivated through international exposure and high level of education), as they can better deal with particularly complex strategic situations (Waldman \& Bowen, 2016).

We therefore find that retail firms can benefit financially from high levels of concurrent internationalization speed in times of economic stability and prosperity, but in times of financial crisis they seem not to enjoy the same benefits by investing in the potentially demanding learning processes associated with both dimensions of internationalization speed. However, since our results are not statistically significant during the financial crisis (neither negative nor positive), they provide no evidence that such a concurrent speed is harmful during such periods. This finding could potentially lend support to a strategy of persevering 
instead of retrenching during times of crises and implies that preserving a concurrent internationalization speed status quo could be a sensible strategy (Wenzel et al., 2020). That said, the fact that we fail to find statistical significance for the post-crisis period does not allow us to make direct inferences and offer safe conclusions. This is also due to the fact that the post-2008 financial crisis did not ultimately end in 2012. Instead, the global economy did suffer from a double dip recession immediately after the 2008 financial crisis. Accordingly, one could assume that the longer than initially anticipated time duration of the financial crisis could have affected internationalizing firms even more adversely. Unfortunately, our lack of data beyond that period does not allow us to examine the magnitude and severity of the financial crisis on the relationship between concurrent internationalization speed and firm performance.

\subsection{Theoretical Implications}

Our study's findings make important theoretical contributions to the literature of international strategy in general and the temporal dimension of internationalization in particular. It does so by, first, highlighting the complexity and multidimensionality of internationalization speed as a process through the introduction and simultaneous assessment of two dimensions of internationalization speed (breadth and depth), and second, its positive impact on firm performance.

First, although multiple dimensions of internationalization speed have been identified and examined in extant literature (e.g., Chetty et al., 2014; Hilmersson \& Johanson, 2016; Meschi et al., 2017), none of these studies have attempted to assess the interaction of such process-oriented speed dimensions with respect to their impact on firm performance. We consider that the interaction of different processoriented dimensions of internationalization speed (breadth and depth) is critical for better understanding the theoretical and practical implications of this phenomenon. This is the literature gap that our study addresses and attempts to fill in.

Second, the mainstream international strategy literature exploring the relationship between internationalization speed and firm performance has been almost exclusively relying on traditional theories, such as that of the Uppsala model (e.g., Meschi et al., 2017), the theory of the growth of the firm and the resource-based view (e.g., Chang \& Rhee, 2011; Mohr \& Batsakis, 2017), organizational learning theory (e.g., García-García et al., 2017), and perspectives embedded in the BG literature (e.g., Hilmersson \& Johanson, 2016). Through drawing insights from paradox theory (Pant \& Ramachandran, 2017; Smith \& Lewis, 2011; Zaheer \& Hernandez, 2011), our study adds a new theoretical perspective in the discussion on the relationship between internationalization speed and firm performance. Our work thus contributes through taking an interdisciplinary approach towards studying an IB-focused research question. Paradox theory is a multifaceted theory that can assist in unveiling the relevant mechanisms and explain complicated processes more effectively. In this regard, its application in IB- and strategy-related studies merits further attention in future research. 
Third, our findings also stress the important role of CEOs in facilitating the process of concurrent internationalization speed and its impact on firm performance. Although scholars have researched the contingent role of internationalization speed on firm performance (García-García et al., 2017; Mohr \& Batsakis, 2017; Yang et al., 2017), to the best of our knowledge there is no prior work investigating the aforementioned relationship with a focus on CEO characteristics. Therefore, firms that seek to embrace the paradox of concurrent internationalization speed should place particular care in their CEO selection. By unveiling the critical role of CEOs, our study makes an important contribution in the UE research with regard to why and how CEO backgrounds might facilitate the temporal dimension of the internationalization process of MNEs. In this manner, it can also be argued that our study provides further support to the Uppsala model (Johanson \& Vahlne, 2009) since this model explains internationalization as a process of learning through the accumulation of experience and knowledge (Hutzschenreuter \& Matt, 2017). More specifically, we demonstrate that a CEO with the relevant experience can facilitate rapid concurrent internationalization and bridge the knowledge gap of the MNE. ${ }^{5}$

\subsection{Managerial Implications}

The findings of this study offer several practical implications. First, this study proves that seemingly contradictory and challenging firm strategies that traditionally compete for the same MNE resources can be jointly determined and leveraged in order for the firm to increase its performance. Managers should thus identify and embrace in such cases paradoxical thinking so their organizations benefit from the interaction of contradictory, yet reconciling forces which, when they coexist, can lead to dynamic and paradoxical unity (Fang, 2012). Second, managers responsible for the international development and expansion of their firms' activities need to distinguish between the breadth and depth dimensions of internationalization speed, as these two dimensions contribute differently in the learning process and performance of the organization. Third, even when firms demonstrate the required competencies to benefit from the concurrent effect of the two different dimensions of internationalization speed, it is suggested that the latter is supported by relevant knowledge absorption capabilities (Theoharakis et al., 2019). Such capabilities are inherent knowledge and valuable information that capable senior leaders (CEOs) have acquired throughout their professional career and can be assessed by the level of their international exposure and education. Finally, managers need to be aware that during financial crises, preserving a high level of concurrent internationalization speed strategy may not necessarily lead to the same positive results in the short-term. However, our findings do not provide evidence that such a strategy might be harmful either.

\footnotetext{
${ }^{5}$ We would like to thank one of the anonymous reviewers for making this suggestion.
} 


\subsection{Limitations and Avenues for Future Research}

Our study has limitations that offer opportunities for future research. First, while our data encompass rich information on observable characteristics of CEOs, these are effectively used as proxies for executives' ability to manage tensions in strategic decision-making. However, the depth of knowledge towards understanding the effect of managerial skills and cognitions on tensions-related strategic decision-making could be further extended with the examination of CEO cognition and psychology-related traits (Zhang et al., 2017). Such information can provide an even more explicit view on how CEO traits facilitate the reconciliation of paradoxical tensions in strategic decision-making. Second, our research setting is purely based on the largest retail MNEs whose purpose is mainly to benefit from market-seeking activities. As a result, generalizations on the implications of our findings towards other industries which for example are characterized by resource- or efficiency-seeking motives, cannot be easily made. Therefore, future research may examine whether the effect of concurrent internationalization speed on firm performance remains a positive one across industries. Third, the fact that our data is available only up to the year 2012 means that we cannot offer insights on more recent trends. Although this is an important limitation, we consider that the longitudinal setting and the 10-year period we cover do compensate for this particular weakness.

In conclusion, we believe that this empirical study is the first to simultaneously examine the performance implications of two different, but equally important, process-related dimensions of rapid internationalization strategy. Also, to the best of our knowledge, our study is the first to examine how CEO observable characteristics can moderate the positive effects stemming from concurrent internationalization speed. Our findings enhance the understanding of how rapidly internationalizing firms in two dimensions (breadth and depth) can more efficiently achieve their financial goals, while we believe that our (empirical and conceptual) approach to view internationalization speed as a multidimensional phenomenon can encourage more future research towards examining this increasingly important research topic. 


\section{Appendix}

Table 3 Cross-sectional time-series FGLS regression on firm performance (ROS) — excluding outliers

\begin{tabular}{|c|c|c|c|c|c|c|c|c|}
\hline & \multicolumn{2}{|l|}{ Model A1.1 } & \multicolumn{2}{|l|}{ Model A1.2 } & \multicolumn{2}{|l|}{ Model A1.3 } & \multicolumn{2}{|l|}{ Model A1.4 } \\
\hline & Coef. & s.e. & Coef. & s.e. & Coef. & s.e. & Coef. & s.e. \\
\hline $\begin{array}{l}\text { CEO International } \\
\text { experience }\end{array}$ & $-1.269 * * *$ & $(0.475)$ & $-1.026^{* *}$ & $(0.451)$ & -0.487 & $(0.592)$ & $-0.934 * *$ & $(0.476)$ \\
\hline CEO education & -0.145 & $(0.106)$ & -0.087 & $(0.106)$ & -0.151 & $(0.104)$ & 0.146 & $(0.238)$ \\
\hline CEO age & $-0.040 * *$ & $(0.020)$ & -0.029 & $(0.019)$ & -0.017 & $(0.019)$ & -0.018 & $(0.020)$ \\
\hline CEO tenure & 0.017 & $(0.024)$ & 0.014 & $(0.023)$ & -0.006 & $(0.019)$ & -0.001 & $(0.023)$ \\
\hline Outside CEO & 0.056 & $(0.220)$ & 0.059 & $(0.213)$ & 0.034 & $(0.212)$ & 0.082 & $(0.223)$ \\
\hline Liquidity ratio & $1.748 * * *$ & $(0.300)$ & $1.662 * * *$ & $(0.302)$ & $1.671^{* * *}$ & $(0.299)$ & $1.628 * * *$ & $(0.305)$ \\
\hline Firm age & $0.014 * * *$ & $(0.004)$ & $0.017^{* * * *}$ & $(0.004)$ & $0.017 * * *$ & $(0.003)$ & $0.016 * * *$ & $(0.004)$ \\
\hline Firm size & 0.126 & $(0.085)$ & 0.096 & $(0.086)$ & 0.091 & $(0.086)$ & 0.111 & $(0.087)$ \\
\hline Firm int. experience & $-0.011^{* * *}$ & $(0.002)$ & $-0.011 * * *$ & $(0.002)$ & $-0.010 * * *$ & $(0.002)$ & $-0.011^{* * *}$ & $(0.002)$ \\
\hline Intangible assets & $-0.054 * * *$ & $(0.013)$ & $-0.054 * * *$ & $(0.012)$ & $-0.051 * * *$ & $(0.011)$ & $-0.049 * * *$ & $(0.012)$ \\
\hline Geographic scope & $0.101 * * *$ & $(0.016)$ & $0.084 * * *$ & $(0.016)$ & $0.072^{* * * *}$ & $(0.016)$ & $0.072 * * *$ & $(0.017)$ \\
\hline $\begin{array}{l}\text { Added cultural } \\
\text { distance }\end{array}$ & -0.054 & $(0.118)$ & -0.055 & $(0.114)$ & -0.068 & $(0.113)$ & -0.087 & $(0.120)$ \\
\hline $\begin{array}{l}\text { (Ln) Home market } \\
\text { size }\end{array}$ & $-0.359^{* *}$ & $(0.149)$ & $-0.302^{* *}$ & $(0.152)$ & -0.205 & $(0.147)$ & $-0.265^{*}$ & $(0.155)$ \\
\hline Financial crisis & $0.487^{*}$ & $(0.267)$ & 0.418 & $(0.262)$ & $0.475^{*}$ & $(0.261)$ & $0.514^{*}$ & $(0.276)$ \\
\hline $\begin{array}{l}\text { Internationalization } \\
\text { speed breadth }\end{array}$ & $-0.197 *$ & $(0.113)$ & $-0.938 * * *$ & $(0.299)$ & $-0.759 * *$ & $(0.340)$ & $2.427 * *$ & $(1.390)$ \\
\hline $\begin{array}{l}\text { Internationalization } \\
\text { speed depth }\end{array}$ & 0.108 & $(0.084)$ & 0.098 & $(0.082)$ & $0.185 * *$ & $(0.097)$ & $0.499 * *$ & $(0.294)$ \\
\hline $\begin{array}{l}\text { Internation- } \\
\text { alization speed } \\
\text { breadth } \times \text { Interna- } \\
\text { tionalization speed } \\
\text { depth }\end{array}$ & & & $0.202 * * *$ & $(0.075)$ & $0.140 * *$ & $(0.086)$ & $-0.796^{* * *}$ & $(0.374)$ \\
\hline $\begin{array}{l}\text { Internation- } \\
\text { alization speed } \\
\text { breadth } \times \text { Interna- } \\
\text { tionalization speed } \\
\text { depth } \times \text { CEO inter- } \\
\text { national experience }\end{array}$ & & & & & $0.440 * *$ & $(0.319)$ & & \\
\hline $\begin{array}{l}\text { Internation- } \\
\text { alization speed } \\
\text { breadth } \times \text { Inter- } \\
\text { nationalization } \\
\text { speed depth } \times \text { CEO } \\
\text { education }\end{array}$ & & & & & & & $0.201 * * *$ & $(0.076)$ \\
\hline Constant & $17.875^{* * *}$ & $(4.045)$ & $15.901 * * *$ & $(4.130)$ & $12.873 * * *$ & (3.986) & $13.027 * * *$ & $(4.342)$ \\
\hline Wald $\mathrm{Chi}^{2}$ & 1701.98 & & $2151.82 * * *$ & & $2194.06^{* * *}$ & & $1932.56^{* * *}$ & \\
\hline
\end{tabular}

FGLS estimator that is robust to first-order panel-specific autocorrelation (AR1) and heteroskedasticity; $* \mathrm{p}<0.10 ; * * \mathrm{p}<0.05 ; * * * \mathrm{p}<0.01$; one-tailed tests for independent and moderating variables; two-tailed tests for controls; Model A1.3 includes the interaction terms of Internationalization speed breadth $\times$ CEO international experience, Internationalization speed depth $\times$ CEO international experience; Model A1.4 includes the interaction terms of Internationalization speed breadth $\times$ CEO education, Internationalization speed depth $\times$ CEO education; The estimates are not reported for brevity; Year and industry dummies are included in all models but their estimates are not reported for brevity; all variables are lagged 1 year. Number of observations $=638$; Number of firms $=91$ 


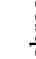

(1)

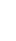

政

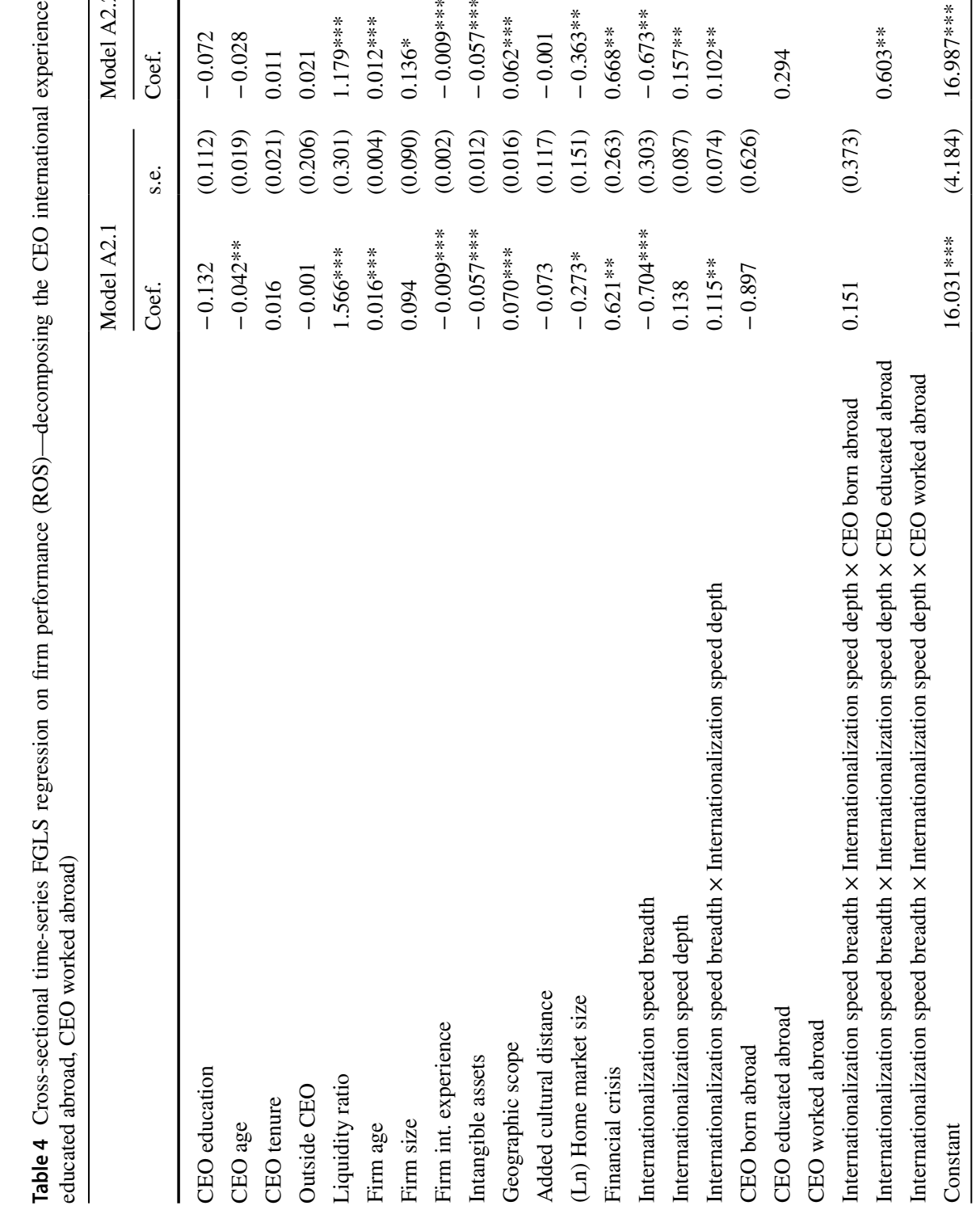




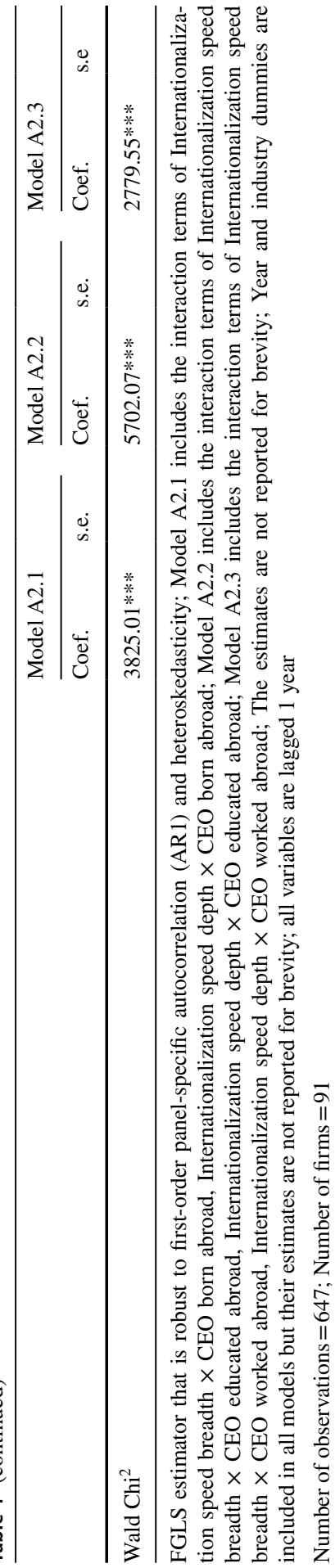


Table 5 Cross-sectional time-series FGLS regression on firm performance (ROS) — exploring quadratic effects

\begin{tabular}{|c|c|c|}
\hline & \multicolumn{2}{|l|}{ Model A3.1 } \\
\hline & Coef. & s.e. \\
\hline CEO international experience & $-1.207 * * *$ & $(0.440)$ \\
\hline CEO education & $-0.195 *$ & $(0.107)$ \\
\hline CEO age & $-0.033^{*}$ & $(0.019)$ \\
\hline CEO tenure & 0.006 & $(0.022)$ \\
\hline Outside CEO & 0.005 & $(0.221)$ \\
\hline Liquidity ratio & $1.878 * * *$ & $(0.294)$ \\
\hline Firm age & $0.016 * * *$ & $(0.004)$ \\
\hline Firm size & 0.061 & $(0.082)$ \\
\hline Firm int. experience & $-0.012 * * *$ & $(0.002)$ \\
\hline Intangible assets & $-0.055^{* * *}$ & $(0.012)$ \\
\hline Geographic scope & $0.107 * * *$ & $(0.016)$ \\
\hline Added cultural distance & 0.000 & $(0.114)$ \\
\hline (Ln) Home market size & $-0.269^{*}$ & $(0.148)$ \\
\hline Financial crisis & $0.591 * *$ & $(0.268)$ \\
\hline Internationalization speed breadth & -1.795 & $(1.669)$ \\
\hline Internationalization speed breadth squared & 0.285 & $(1.698)$ \\
\hline Internationalization speed depth & -0.184 & $(0.247)$ \\
\hline Internationalization speed depth squared & 0.057 & $(0.046)$ \\
\hline Internationalization speed breadth $\times$ Internationalization speed depth & 1.036 & $(0.946)$ \\
\hline Internationalization speed breadth squared $\times$ Internationalization speed depth & -0.357 & $(0.862)$ \\
\hline Internationalization speed depth squared $\times$ Internationalization speed breadth & -0.128 & $(0.127)$ \\
\hline $\begin{array}{l}\text { Internationalization speed breadth squared } \times \text { Internationalization speed depth } \\
\text { squared }\end{array}$ & 0.054 & $(0.102)$ \\
\hline Constant & $16.550 * * *$ & $(3.976)$ \\
\hline Wald $\mathrm{Chi}^{2}$ & $2114.49 * * *$ & \\
\hline
\end{tabular}

FGLS estimator that is robust to first-order panel-specific autocorrelation (AR1) and heteroskedasticity; Year and industry dummies are included in all models but their estimates are not reported for brevity; all variables are lagged 1 year. Number of observations $=647$; Number of firms $=91$ 


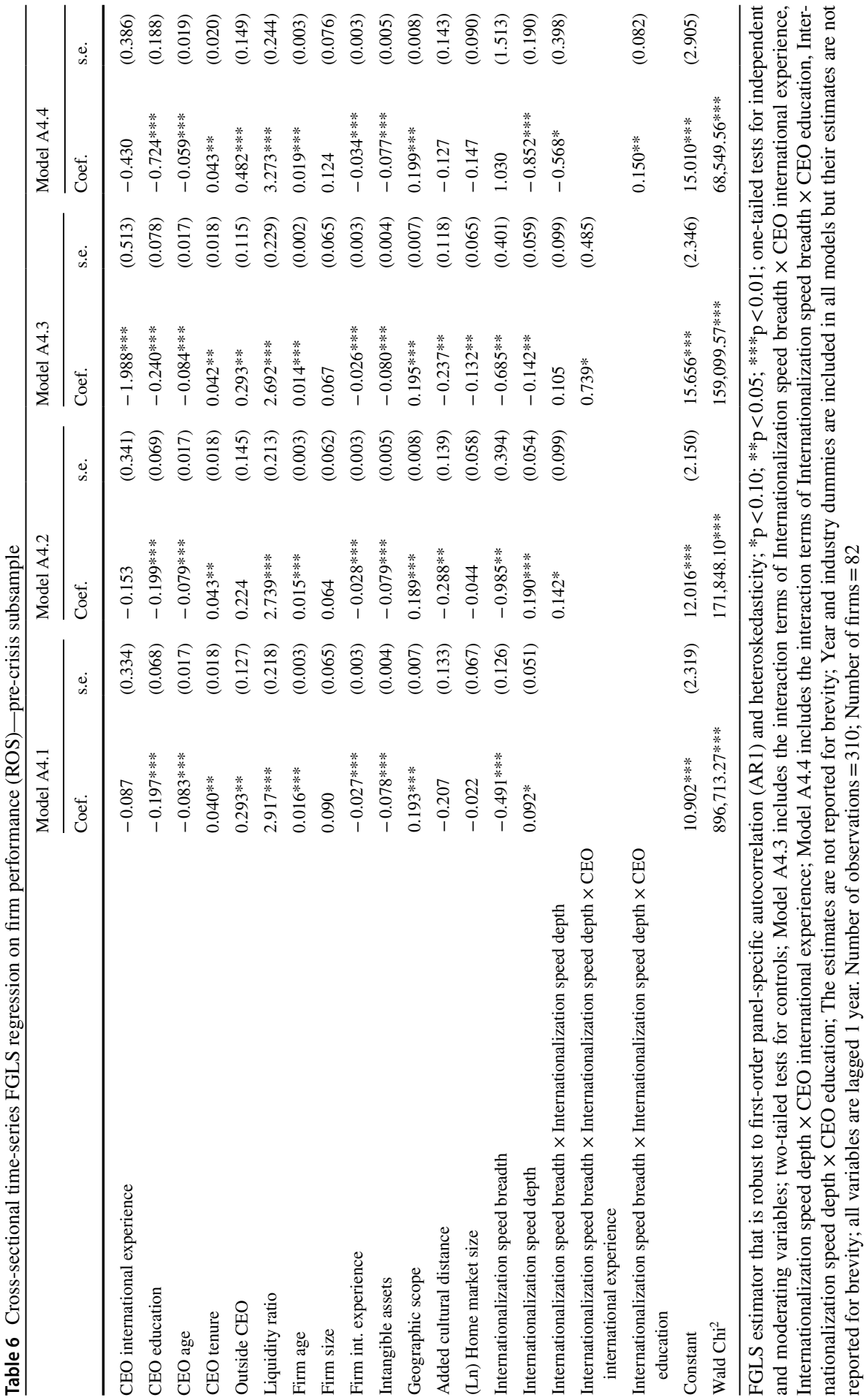




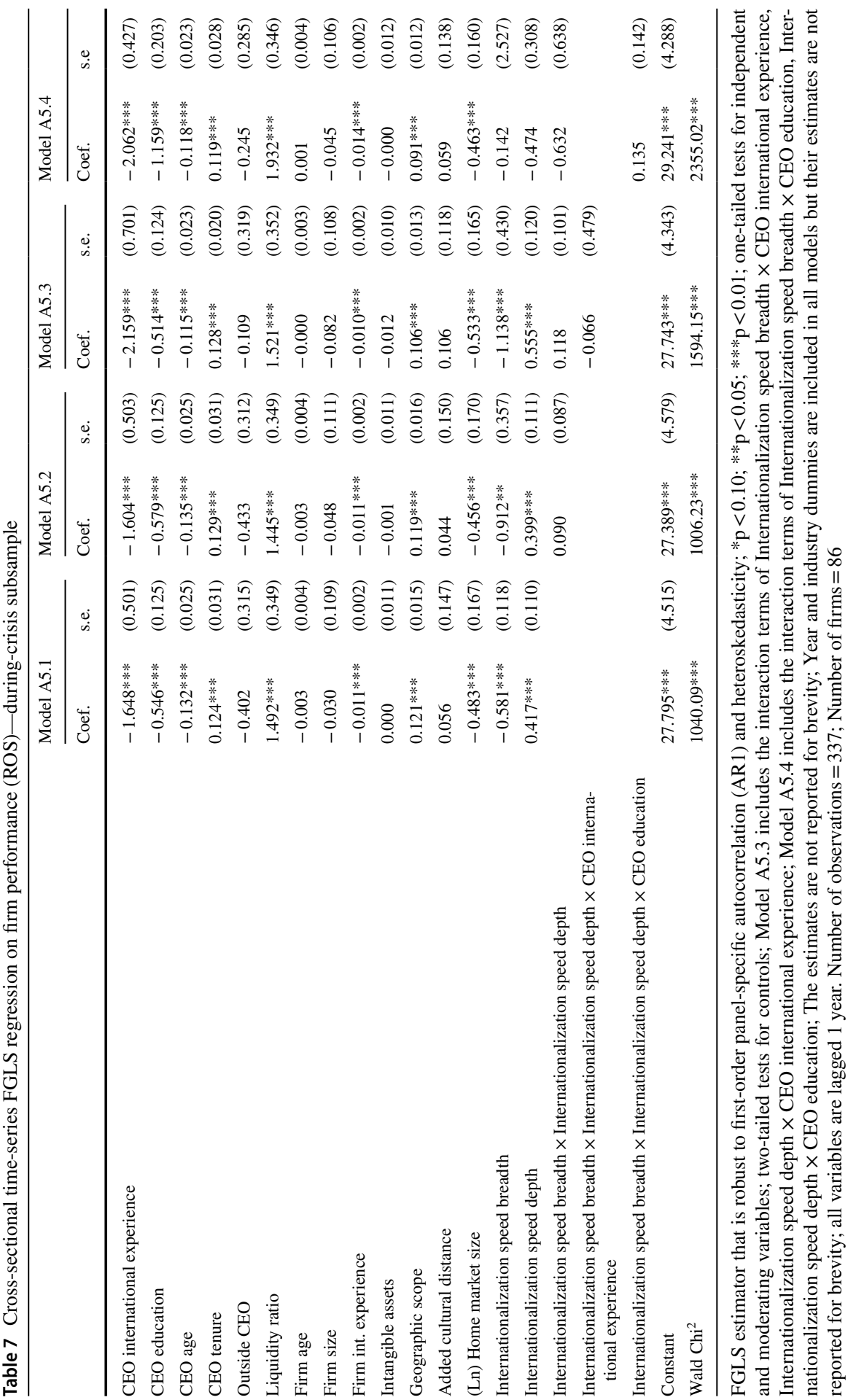


Open Access This article is licensed under a Creative Commons Attribution 4.0 International License, which permits use, sharing, adaptation, distribution and reproduction in any medium or format, as long as you give appropriate credit to the original author(s) and the source, provide a link to the Creative Commons licence, and indicate if changes were made. The images or other third party material in this article are included in the article's Creative Commons licence, unless indicated otherwise in a credit line to the material. If material is not included in the article's Creative Commons licence and your intended use is not permitted by statutory regulation or exceeds the permitted use, you will need to obtain permission directly from the copyright holder. To view a copy of this licence, visit http://creativecommons.org/licen ses/by/4.0/.

\section{References}

Acedo, F. J., \& Jones, M. V. (2007). Speed of internationalization and entrepreneurial cognition: Insights and a comparison between international new ventures, exporters and domestic firms. Journal of World Business, 42(3), 236-252.

Aiken, L. S., \& West, S. G. (1991). Multiple regression: Testing and interpreting interactions. Sage.

Amason, A. C. (1996). Distinguishing the effects of functional and dysfunctional conflict on strategic decision making: Resolving a paradox for top management teams. Academy of Management Journal, 39(1), 123-148.

Barkema, H., Bell, J., \& Pennings, J. (1996). Foreign entry, cultural barriers, and learning. Strategic Management Journal, 17(2), 151-166.

Barkema, H. G., \& Drogendijk, R. (2007). Internationalising in small, incremental or larger steps? Journal of International Business Studies, 38(7), 1132-1148. https://doi.org/10.1057/palgrave.jibs. 8400315

Batsakis, G., \& Mohr, A. (2017). Revisiting the relationship between product diversification and internationalization process in the context of emerging market MNEs. Journal of World Business, 52(4), 564-577. https://doi.org/10.1016/j.jwb.2016.11.005

Bercovitz, J., \& Mitchell, W. (2007). When is more better? The impact of business scale and scope on long-term business survival, while controlling for profitability. Strategic Management Journal, 28(1), 61-79. https://doi.org/10.1002/smj

Bonaglia, F., Goldstein, A., \& Mathews, J. A. (2007). Accelerated internationalization by emerging markets' multinationals: The case of the white goods sector. Journal of World Business, 42(4), 369-383.

Bouquet, C., Morrison, A., \& Birkinshaw, J. (2009). International attention and multinational enterprise performance. Journal of International Business Studies, 40(1), 108-131.

Bruton, G. D., Ahlstrom, D., \& Wan, J. C. C. (2003). Turnaround in East Asian firms: Evidence from ethnic overseas Chinese communities. Strategic Management Journal, 24(6), 519-540.

Capar, N., \& Kotabe, M. (2003). The relationship between international diversification and performance in service firms. Journal of International Business Studies, 34(4), 345-355. https://doi. org/10.1057/palgrave.jibs.8400036

Carpenter, M. A., \& Geletkanycz, M. A. (2004). Upper echelons research revisited: Antecedents, elements, and consequences of top management team composition. Journal of Management, 30(6), 749-778. https://doi.org/10.1016/j.jm.2004.06.001

Carpenter, M. A., \& Sanders, W. G. (2004). The effects of top management team pay and firm internationalization on MNC performance. Journal of Management, 30(4), 509-528.

Carpenter, M. A., Sanders, W. G., \& Gregersen, H. B. (2001). Bundling human capital with organizational context: The impact of international assignment experience on multinational firm performance and CEO pay. Academy of Management Journal, 44(3), 493-511.

Casillas, J. C., \& Moreno-Menéndez, A. M. (2014). Speed of the internationalization process: The role of diversity and depth in experiential learning. Journal of International Business Studies, 45(1), 85-101. https://doi.org/10.1057/jibs.2013.29

Cavusgil, S. T., \& Knight, G. (2015). The born global firm: An entrepreneurial and capabilities perspective on early and rapid internationalization. Journal of International Business Studies, 46(1), 3-16. 
Chang, S.-J., Chung, J., \& Jungbien Moon, J. (2013). When do foreign subsidiaries outperform local firms? Journal of International Business Studies, 44(8), 853-860. https://doi.org/10.1057/jibs. 2013.35

Chang, S.-J., \& Rhee, J. H. (2011). Rapid FDI expansion and firm performance. Journal of International Business Studies, 42(8), 979-994. https://doi.org/10.1057/jibs.2011.30

Chetty, S., \& Campbell-Hunt, C. (2004). A strategic approach to internationalization: A traditional versus a "born-global" approach. Journal of International Marketing, 12(1), 57-81.

Chetty, S., Johanson, M., \& Martín Martín, O. (2014). Speed of internationalization: Conceptualization, measurement and validation. Journal of World Business, 49(4), 633-650. https://doi.org/10.1016/j. jwb.2013.12.014

Coe, N. M., \& Wrigley, N. (2007). Host economy impacts of transnational retail: The research agenda. Journal of Economic Geography, 7(4), 341-371.

Contractor, F. J., Kundu, S. K., \& Hsu, C. C. (2003). A three-stage theory of international expansion: The link between multinationality and performance in the service sector. Journal of International Business Studies, 34(1), 5-18

Costanzo, L. A., \& Di Domenico, M. (2015). A Multi-level dialectical-paradox lens for top management team strategic decision-making in a corporate venture. British Journal of Management, 26(3), 484-506.

Daily, C. M., Certo, S. T., \& Dalton, D. R. (2000). International experience in the executive suite: The path to prosperity? Strategic Management Journal, 21(4), 515-523.

Datta, D. K., \& Rajagopalan, N. (1998). Industry structure and CEO characteristics: An empirical study of succession events. Strategic Management Journal, 19(9), 833-852.

De Bono, E. (1971). New think: The use of lateral thinking in the generation of new ideas. Avon Books.

de Figueiredo Jr, R. J. P., Feldman, E. R., \& Rawley, E. (2019). The costs of refocusing: Evidence from hedge fund closures during the financial crisis. Strategic Management Journal, 40(8), 1268-1290.

Deloitte. (2011). Leaving Home - Global Powers of Retailing. Deloitte.

Dierickx, I., \& Cool, K. (1989). Asset stock accumulation and sustainability of competitive advantage. Management Science, 35(12), 1504-1511.

Eden, L. (2009). Letter from the editor-in-chief: Time in international business. Springer.

Eisenhardt, K. M., \& Brown, S. L. (1998). Competing on the edge: Strategy as structured chaos. Long Range Planning, 31(5), 786-789.

Fang, T. (2012). Yin Yang: A new perspective on culture. Management and Organization Review, 8(1), 25-50.

Frank, M. Z., \& Goyal, V. K. (2007). Corporate leverage: How much do managers really matter? Working Paper, University of Minnesota and Hong Kong University of Science and Technology.

Fredberg, T. (2014). If I say it's complex, it bloody well will be: CEO strategies for managing paradox. The Journal of Applied Behavioral Science, 50(2), 171-188.

García-García, R., García-Canal, E., \& Guillén, M. F. (2017). Rapid internationalization and long-term performance: The knowledge link. Journal of World Business, 52(1), 97-110.

Geringer, M. J., Beamish, P. W., \& Da Costa, R. C. (1989). Diversification strategy and internationalization: Implications for MNE performance. Strategic Management Journal, 10(2), 109-119.

Ghemawat, P., \& Nueno, J. (2006). Case Zara, fast fashion. Boston, Harvard Business School Study Case.

Goll, I., Johnson, N. B., \& Rasheed, A. A. (2007). Knowledge capability, strategic change, and firm performance. Management Decision, 45(2), 161-179.

Gounopoulos, D., Loukopoulos, G., \& Loukopoulos, P. (2020). CEO education and the ability to raise capital. Corporate Governance: an International Review, 29(1), 67-99. https://doi.org/10.1111/ corg. 12338

Grant, R. M., Jammine, A. P., \& Thomas, H. (1988). Diversity, diversification, and profitability among British manufacturing companies 1972-84. Academy of Management Journal, 31(4), 771-801. https://doi.org/10.2307/256338

Hambrick, D. C. (2007). Upper echelons theory: An update. Academy of Management Review, 32(2), 334-343.

Hambrick, D. C., \& Mason, P. A. (1984). Upper echelons: The organization as a reflection of its top managers. Academy of Management Review, 9(2), 193-206.

Henderson, A. D., Miller, D., \& Hambrick, D. C. (2006). How quickly do CEOs become obsolete? Industry dynamism, CEO tenure, and company performance. Strategic Management Journal, 27(5), 447-460. https://doi.org/10.1002/smj.524

Hennart, J.-F. (1982). A theory of multinational enterprise. University of Michigan Press. 
Heracleous, L., \& Wirtz, J. (2014). Singapore Airlines: Achieving sustainable advantage through mastering paradox. The Journal of Applied Behavioral Science, 50(2), 150-170.

Herrmann, P., \& Datta, D. K. (2002). CEO successor characteristics and the choice of foreign market entry mode: An empirical study. Journal of International Business Studies, 33(3), 551-569.

Herrmann, P., \& Datta, D. K. (2005). Relationships between top management team characteristics and international diversification: An empirical investigation. British Journal of Management, 16(1), 69-78. https://doi.org/10.1111/j.1467-8551.2005.00429.x

Hilmersson, M., \& Johanson, M. (2016). Speed of SME internationalization and performance. Management International Review, 56(1), 67-94. https://doi.org/10.1007/s11575-015-0257-4

Hitt, M. A., Li, D., \& Xu, K. (2016). International strategy: From local to global and beyond. Journal of World Business, 51(1), 58-73.

Hofstede, G. H. (2001). Culture's consequences: Comparing values, behaviors, institutions and organizations across nations. Sage.

Hsieh, L., Child, J., Narooz, R., Elbanna, S., Karmowska, J., Marinova, S., Puthusserry, P., Tsai, T., \& Zhang, Y. (2019). A multidimensional perspective of SME internationalization speed: The influence of entrepreneurial characteristics. International Business Review, 28(2), 268-283.

Hsu, C. C., \& Boggs, D. J. (2003). Internationalization and performance: Traditional measures and their decomposition. Multinational Business Review, 11(3), 23-50. https://doi.org/10.1108/1525383X20 0300015

Hsu, W.-T., Chen, H.-L., \& Cheng, C.-Y. (2013). Internationalization and firm performance of SMEs: The moderating effects of CEO attributes. Journal of World Business, 48(1), 1-12. https://doi.org/10. 1016/j.jwb.2012.06.001

Hutzschenreuter, T., \& Harhoff, P.-L. (2020). National capital city location and subsidiary portfolio expansion: The negative effect of geographic distance to the capital city at inception on the speed of subsequent investments. Journal of International Business Studies, 51(7), 1107-1132. https:// doi.org/10.1057/s41267-020-00305-1

Hutzschenreuter, T., \& Horstkotte, J. (2013). Performance effects of international expansion processes: The moderating role of top management team experiences. International Business Review, 22(1), 259-277. https://doi.org/10.1016/j.ibusrev.2012.04.006

Hutzschenreuter, T., Kleindienst, I., \& Lange, S. (2014). Added psychic distance stimuli and MNE performance. Journal of International Management, 20(1), 38-54. https://doi.org/10.1016/j.intman. 2013.02.003

Hutzschenreuter, T., \& Matt, T. (2017). MNE internationalization patterns, the roles of knowledge stocks, and the portfolio of MNE subsidiaries. Journal of International Business Studies, 48(9), 1131-1150.

Hutzschenreuter, T., \& Voll, J. C. (2008). Performance effects of "added cultural distance" in the path of international expansion: The case of German multinational enterprises. Journal of International Business Studies, 39(1), 53-70. https://doi.org/10.1057/palgrave.jibs.8400312

Hymer, S. (1960). The international operations of national firms: A study of direct foreign investment. MIT Press.

Jain, N. K., Pangarkar, N., Yuan, L., \& Kumar, V. (2019). Rapid internationalization of emerging market firms-The role of geographic diversity and added cultural distance. International Business Review, 28(6), 101590.

Jiang, R. J., Beamish, P. W., \& Makino, S. (2014). Time compression diseconomies in foreign expansion. Journal of World Business, 49(1), 114-121. https://doi.org/10.1016/j.jwb.2013.02.003

Johanson, J., \& Vahlne, J. (1977). The internationalization process of the firm-A model of knowledge development and increasing foreign market commitments. Journal of International Business Studies, 8(1), 23-32.

Johanson, J., \& Vahlne, J.-E. (2009). The Uppsala internationalization process model revisited: From liability of foreignness to liability of outsidership. Journal of International Business Studies, 40(9), 1411-1431. https://doi.org/10.1057/jibs.2009.24

Jones, M. V., \& Coviello, N. E. (2005). Internationalisation: Conceptualising an entrepreneurial process of behaviour in time. Journal of International Business Studies, 36(3), 284-303.

Kafouros, M. I., Buckley, P. J., \& Clegg, J. (2014). The effects of global knowledge reservoirs on the productivity of multinational enterprise: The role of international depth and breadth. In P. J. Buckley (Ed.), The multinational enterprise and the emergence of the global factory (pp. 220-254). Springer. 
Katila, R., \& Ahuja, G. (2002). Something old, something new: A longitudinal study of search behavior and new product introduction. Academy of Management Journal, 45(6), 1183-1194.

Kim, H., Wu, J., Schuler, D. A., \& Hoskisson, R. E. (2020). Chinese multinationals' fast internationalization: Financial performance advantage in one region, disadvantage in another. Journal of International Business Studies, 51(7), 1076-1106. https://doi.org/10.1057/s41267-019-00279-9

King, T., Srivastav, A., \& Williams, J. (2016). What's in an education? Implications of CEO education for bank performance. Journal of Corporate Finance, 37, 287-308.

Knott, A. M., Bryce, D. J., \& Posen, H. E. (2003). On the strategic accumulation of intangible assets. Organization Science, 14(2), 192-207.

Kogut, B., \& Singh, H. (1988). The effect of national culture on the choice of entry mode. Journal of International Business Studies, 19(3), 411-432.

Kundu, S. K., \& Lahiri, S. (2015). Turning the spotlight on service multinationals: New theoretical insights and empirical evidence. Journal of International Management, 21(3), 215-219.

Le, S., \& Kroll, M. (2017). CEO international experience: Effects on strategic change and firm performance. Journal of International Business Studies, 48(5), 573-595. https://doi.org/10.1057/ s41267-017-0080-1

Lee, H., \& Park, J. (2008). The influence of top management team international exposure on international alliance formation. Journal of Management Studies, 45(5), 961-981.

Lee, S., \& Makhija, M. (2009). Flexibility in internationalization: Is it valuable during an economic crisis? Strategic Management Journal, 30(5), 537-555.

Lewis, M. W. (2000). Exploring paradox: Toward a more comprehensive guide. Academy of Management Review, 25(4), 760-776.

Lewis, M. W., Andriopoulos, C., \& Smith, W. K. (2014). Paradoxical leadership to enable strategic agility. California Management Review, 56(3), 58-77.

Li, L., Gongming, Q., \& Zhenming, Q. (2013). Breadth and depth of international diversification: Interactions, trade-offs and profitability. Journal of General Management, 39(1), 3-25.

Li, L., Qian, G., \& Qian, Z. (2015). Speed of internationalization: Mutual effects of individual-and company-level antecedents. Global Strategy Journal, 5(4), 303-320.

Luo, Y., \& Rui, H. (2009). An ambidexterity perspective toward multinational enterprises from emerging economies. Academy of Management Perspectives, 23(4), 49-70.

Luo, Y., \& Tung, R. L. (2007). International expansion of emerging market enterprises: A springboard perspective. Journal of International Business Studies, 38(4), 481-498. https://doi.org/10.1057/ palgrave.jibs. 8400275

Makino, S., Lau, C.-M., \& Yeh, R.-S. (2002). Asset-exploitation versus asset-seeking: Implications for location choice of foreign direct investment from newly industrialized economies. Journal of International Business Studies, 33(3), 403-421.

March, J. G. (1991). Exploration and exploitation in organizational learning. Organization Science, 2(1), 71-87. https://doi.org/10.1287/orsc.2.1.71

Mathews, J. A. (2006). Dragon multinationals: New players in 21st century globalization. Asia Pacific Journal of Management, 23(1), 5-27. https://doi.org/10.1007/s10490-006-6113-0

Melin, L. (1992). Internationalization as a strategy process. Strategic Management Journal, 13, 99-118.

Meschi, P., Ricard, A., \& Tapia, E. (2017). Fast and furious or slow and cautious? The joint impact of age at internationalization, speed, and risk diversity on the survival of exporting firms. Journal of International Management, 23(3), 279-291. https://doi.org/10.1016/j.intman.2017.01.001

Miron-Spektor, E., Ingram, A., Keller, J., Smith, W. K., \& Lewis, M. W. (2018). Microfoundations of organizational paradox: The problem is how we think about the problem. Academy of Management Journal, 61(1), 26-45.

Mohr, A., \& Batsakis, G. (2017). Internationalization speed and firm performance: A study of the marketseeking expansion of retail MNEs. Management International Review, 57(2), 153-177. https://doi. org/10.1007/s11575-016-0284-9

Mohr, A., \& Batsakis, G. (2018). Firm resources, cultural distance and simultaneous international expansion in the retail sector. International Business Review, 27(1), 113-124. https://doi.org/10.1016/j. ibusrev.2017.05.010

Mohr, A., \& Batsakis, G. (2019). The contingent effect of TMT international experience on firms' internationalization speed. British Journal of Management, 30(4), 869-887. https://doi.org/10.1111/ 1467-8551.12293 
Mohr, A., Batsakis, G., \& Stone, Z. (2018). Explaining the effect of rapid internationalization on horizontal foreign divestment in the retail sector: An extended Penrosean perspective. Journal of International Business Studies, 49(7), 779-808. https://doi.org/10.1057/s41267-017-0138-0

Mohr, A., Fastoso, F., Wang, C., \& Shirodkar, V. (2014). Testing the regional performance of multinational enterprises in the retail sector: The moderating effects of timing, speed and experience. British Journal of Management, 25, S100-S115. https://doi.org/10.1111/1467-8551.12013

Nadkarni, S., Herrmann, P., \& Perez, P. (2011). Domestic mindsets and early international performance: The moderating effect of global industry conditions. Strategic Management Journal, 32(5), 510531. https://doi.org/10.1002/smj

Nadolska, A., \& Barkema, H. G. (2007). Learning to internationalise: The pace and success of foreign acquisitions. Journal of International Business Studies, 38(7), 1170-1186. https://doi.org/10.1057/ palgrave.jibs.8400318

Nielsen, B. B., \& Nielsen, S. (2011). The role of top management team international orientation in international strategic decision-making: The choice of foreign entry mode. Journal of World Business, 46(2), 185-193. https://doi.org/10.1016/j.jwb.2010.05.003

O'Grady, S., \& Lane, H. (1996). The psychic distance paradox. Journal of International Business Studies, 27(2), 309-333.

Oviatt, B. M., \& McDougall, P. P. (2005). Defining international entrepreneurship and modeling the speed of internationalization. Entrepreneurship Theory and Practice, 29(5), 537-553.

Pant, A., \& Ramachandran, J. (2017). Navigating identity duality in multinational subsidiaries: A paradox lens on identity claims at Hindustan Unilever 1959-2015. Journal of International Business Studies, 48(6), 664-692. https://doi.org/10.1057/s41267-017-0076-x

Penrose, E. T. (1959). The theory of the growth of the firm. Wiley.

Perrewé, P. L., Ferris, G. R., Frink, D. D., \& Anthony, W. P. (2000). Political skill: An antidote for workplace stressors. Academy of Management Perspectives, 14(3), 115-123.

Piaskowska, D., \& Trojanowski, G. (2014). Twice as smart? The importance of managers' formativeyears' international experience for their international orientation and foreign acquisition decisions. British Journal of Management, 25(1), 40-57. https://doi.org/10.1111/j.1467-8551.2012.00831.x

Pogrebnyakov, N., \& Maitland, C. F. (2011). Institutional distance and the internationalization process: The case of mobile operators. Journal of International Management, 17(1), 68-82.

Powell, K. S. (2013). Profitability and speed of foreign market entry. Management International Review, 54(1), 31-45. https://doi.org/10.1007/s11575-013-0184-1

Qian, G., Li, L., \& Qian, Z. (2018). Interactions among factors driving and inhibiting the early internationalization of small, young technology enterprises. Management International Review, 58(2), 251-280.

Reuber, A. R., \& Fischer, E. (1997). The influence of the management team's international experience on the internationalization behaviors of SMEs. Journal of International Business Studies, 28(4), $807-825$.

Rost, K., \& Osterloh, M. (2010). Opening the black box of upper echelons: Drivers of poor information processing during the financial crisis. Corporate Governance: An International Review, 18(3), 212-233.

Smit, H., Pennings, E., \& van Bekkum, S. (2017). Real options and institutions. Journal of International Business Studies, 48(5), 620-644.

Smith, W. K., \& Lewis, M. W. (2011). Toward a theory of paradox: A dynamic equilibrium model of organizing. Academy of Management Review, 36(2), 381-403.

Strike, V. M., Gao, J., \& Bansal, P. (2006). Being good while being bad: Social responsibility and the international diversification of US firms. Journal of International Business Studies, 37(6), $850-862$.

Sturman, M. (2003). Searching for the inverted U-shaped relationship between time and performance: Meta-analyses of the experience/performance, tenure/performance, and age/performance relationships. Journal of Management, 29(5), 609-640. https://doi.org/10.1016/S0149-2063(03)00028-X

Tang, R. W. (2019). FDI expansion speed of state-owned enterprises and the moderating role of market capitalism: Evidence from China. International Business Review, 28(6), 101596.

Theoharakis, V., Angelis, Y., \& Batsakis, G. (2019). Architectural marketing capabilities of exporting ventures: The contingent effect of the distributor. International Marketing Review, 36(6), 10261041. https://doi.org/10.1108/IMR-02-2019-0081

Tihanyi, L., Ellstrand, A. E., Daily, C. M., \& Dalton, D. R. (2000). Composition of the top management team and firm international diversification. Journal of Management, 26(6), 1157-1177. 
UNCTAD. (2012). World Investment Report. UNITED NATIONS PUBLICATION.

Vaaler, P. M. (2011). Immigrant remittances and the venture investment environment of developing countries. Journal of International Business Studies, 42(9), 1121-1149.

Vahlne, J.-E., \& Johanson, J. (2017). From internationalization to evolution: The Uppsala model at 40 years. Journal of International Business Studies, 48(9), 1087-1102. https://doi.org/10.1057/ s41267-017-0107-7

Vermeulen, F., \& Barkema, H. (2002). Pace, rhythm, and scope: Process dependence in building a profitable multinational corporation. Strategic Management Journal, 23(7), 637-653. https://doi.org/10. $1002 / \mathrm{smj} .243$

Vernon, R. (1966). International investment and international trade in the product cycle. The Quarterly Journal of Economics, 80(2), 190-207. https://doi.org/10.1086/270156

Wagner, H. (2004). Internationalization speed and cost efficiency: Evidence from Germany. International Business Review, 13(4), 447-463. https://doi.org/10.1016/j.ibusrev.2004.05.001

Waldman, D. A., \& Bowen, D. E. (2016). Learning to be a paradox-savvy leader. Academy of Management Perspectives, 30(3), 316-327.

Wang, S. L., Luo, Y., Maksimov, V., Sun, J., \& Celly, N. (2018). Achieving temporal ambidexterity in new ventures. Journal of Management Studies, 56(4), 788-822. https://doi.org/10.1111/joms. 12431

Wenzel, M., Stanske, S., \& Lieberman, M. B. (2020). Strategic responses to crisis. Strategic Management Journal, 42(2), O16-O27.

Wiersema, M. F., \& Bantel, K. A. (1992). Top management team demography and corporate strategic change. Academy of Management Journal, 35(1), 91-121.

Wooldridge, J. M. (2010). Econometric analysis of cross section and panel data. MIT Press.

Xue, R., Qian, G., Qian, Z., \& Li, L. (2021). Entrepreneurs' implicit and explicit achievement motives and their early international commitment. Management International Review, 61(1), 91-121.

Yang, J. Y., Lu, J., \& Jiang, R. (2017). Too slow or too fast? Speed of FDI expansions, industry globalization, and firm performance. Long Range Planning, 50(1), 74-92.

Yang, L.-Q., Spector, P. E., Sanchez, J. I., Allen, T. D., Poelmans, S., Cooper, C. L., Lapierre, L. M., O’Driscoll, M. P., Abarca, N., Alexandrova, M., Antoniou, A.-S., Beham, B., Brough, P., Çarikçi, I., Ferreiro, P., Fraile. G., Geurts, S., Kinnunen, U., Lu, C.-Q., et al. (2012). Individualism-collectivism as a moderator of the work demands-strains relationship: A cross-level and cross-national examination. Journal of International Business Studies, 43(4), 424-443.

Zaheer, A., \& Hernandez, E. (2011). The geographic scope of the MNC and its alliance portfolio: Resolving the paradox of distance. Global Strategy Journal, 1(1-2), 109-126. https://doi.org/10.1002/ gsj.6

Zahra, S., Ireland, R., \& Hitt, M. (2000). International expansion by new venture firms: International diversity, mode of market entry, technological learning, and performance. Academy of Management Journal, 43(5), 925-950.

Zhang, H., Ou, A. Y., Tsui, A. S., \& Wang, H. (2017). CEO humility, narcissism and firm innovation: A paradox perspective on CEO traits. The Leadership Quarterly, 28(5), 585-604.

Zhang, Y., \& Rajagopalan, N. (2010). Once an outsider, always an outsider? CEO origin, strategic chane, and firm performance. Strategic Management Journal, 31(3), 334-346. https://doi.org/10.1002/smj

Zhang, Y., \& Wiersema, M. F. (2009). Stock market reaction to CEO certification: The signaling role of CEO background. Strategic Management Journal, 30(7), 693-710.

Publisher's Note Springer Nature remains neutral with regard to jurisdictional claims in published maps and institutional affiliations. 